April $2000 \quad$ • NREL/TP-550-27635

\title{
National Status Report Home Energy Rating Systems and Energy-Efficient Mortgages
}

Patricia C. Plympton C.E.M.

\section{National Renewable Energy Laboratory}

1617 Cole Boulevard

Golden, Colorado 80401-3393

NREL is a U.S. Department of Energy Laboratory

Operated by Midwest Research Institute • Battelle • Bechtel

Contract No. DE-AC36-99-G010337 


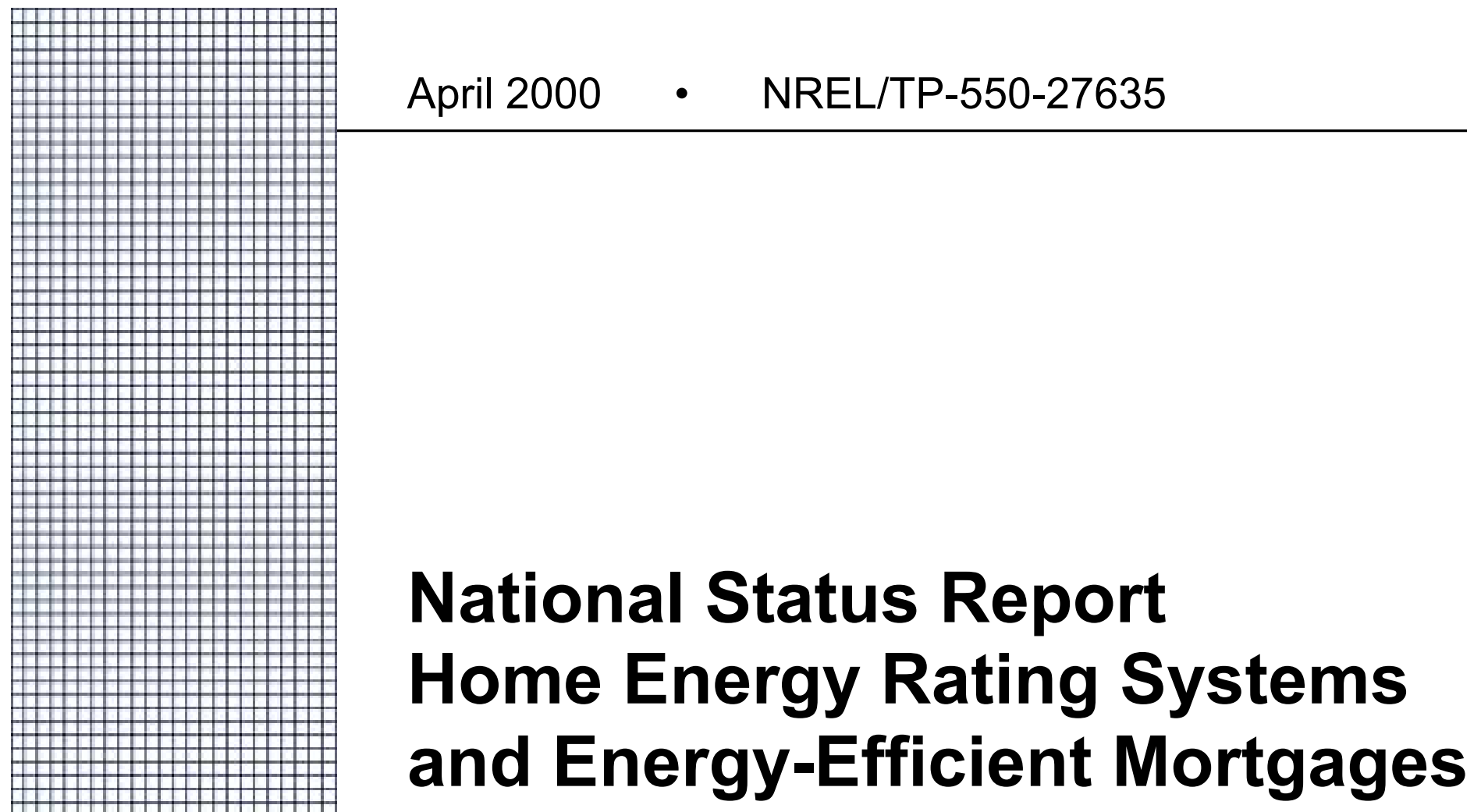

Patricia C. Plympton C.E.M.

Prepared under Task No. BE90.1001

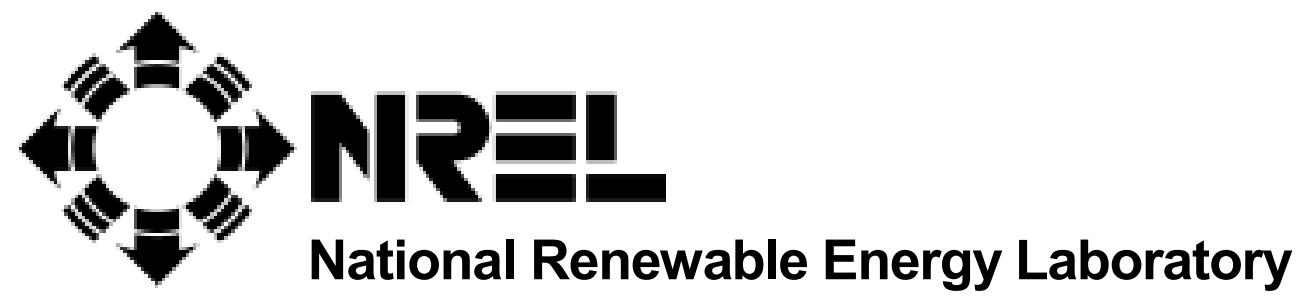

1617 Cole Boulevard

Golden, Colorado 80401-3393

NREL is a U.S. Department of Energy Laboratory

Operated by Midwest Research Institute $\bullet$ Battelle $\bullet$ Bechtel

Contract No. DE-AC36-99-G010337 


\section{NOTICE}

This report was prepared as an account of work sponsored by an agency of the United States government. Neither the United States government nor any agency thereof, nor any of their employees, makes any warranty, express or implied, or assumes any legal liability or responsibility for the accuracy, completeness, or usefulness of any information, apparatus, product, or process disclosed, or represents that its use would not infringe privately owned rights. Reference herein to any specific commercial product, process, or service by trade name, trademark, manufacturer, or otherwise does not necessarily constitute or imply its endorsement, recommendation, or favoring by the United States government or any agency thereof. The views and opinions of authors expressed herein do not necessarily state or reflect those of the United States government or any agency thereof.

Available electronically at http://www.doe.gov/bridge

Available for a processing fee to U.S. Department of Energy and its contractors, in paper, from:

U.S. Department of Energy

Office of Scientific and Technical Information

P.O. Box 62

Oak Ridge, TN 37831-0062

phone: 865.576 .8401

fax: 865.576.5728

email: reports@adonis.osti.gov

Available for sale to the public, in paper, from:

U.S. Department of Commerce

National Technical Information Service

5285 Port Royal Road

Springfield, VA 22161

phone: 800.553.6847

fax: 703.605.6900

email: orders@ntis.fedworld.gov

online ordering: http://www.ntis.gov/ordering.htm

Printed on paper containing at least $50 \%$ wastepaper, including $20 \%$ postconsumer waste 


\section{Table of Contents}

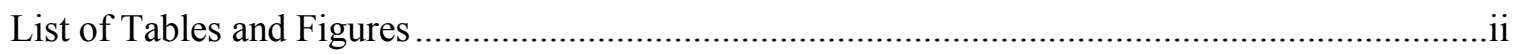

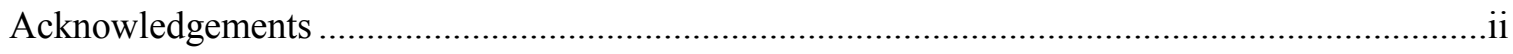

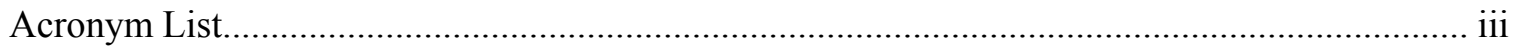

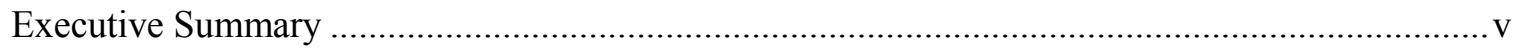

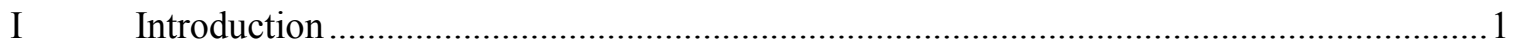

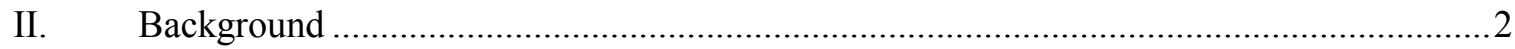

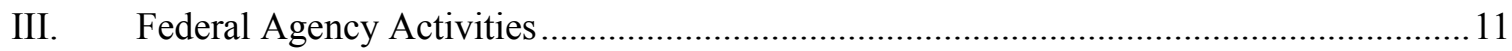

1. DOE Five-year pilot of HERS Provider Organizations …......................................... 11

2. DOE State Energy Program HERS Grants .............................................................. 14

3. U.S. Department of Housing and Urban Development Federal Housing Administration Energy-Efficient Mortgages ......................................................... 15

4. Department of Veterans Affairs Energy-Efficient Mortgages .....................................16

5. U.S. Department of Agriculture Rural Housing Service Guaranteed and Direct

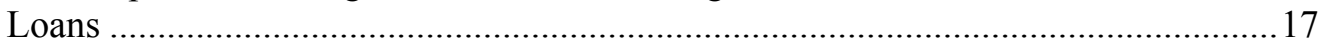

6. U.S. Environmental Protection Agency ENERGY STAR Homes .............................. 17

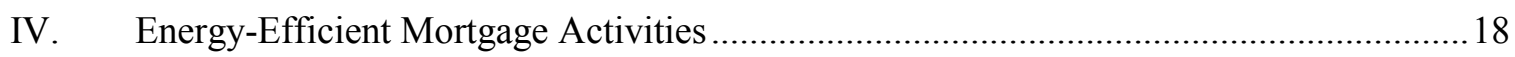

1. Secondary Mortgage Market, Government-Sponsored Enterprises ...........................19

2. National Primary Lenders with Energy-Efficient Mortgage Programs .......................21

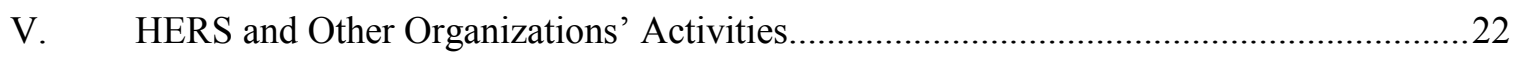

1. HERS Council, Voluntary National Ratings Guidelines and National Association of State Energy Officials / Residential Energy Services Network Guidelines ...........22

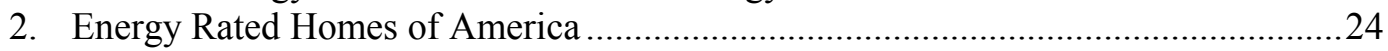

3. National Home Energy \& Resources Organization..................................................2 24

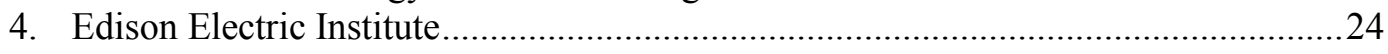

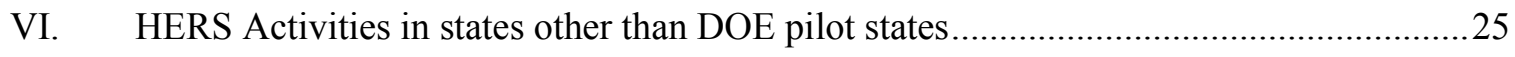

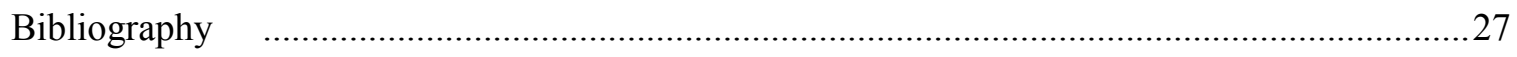

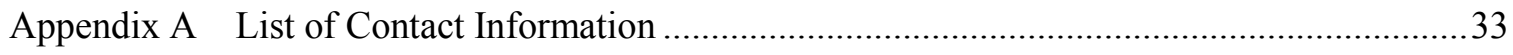




\section{List of Tables}

Table 1. HERS and other Residential Energy Efficiency Programs, as of Fall 1999 .....................

Table 2. National EEM Programs for Existing Home................................................................... 5

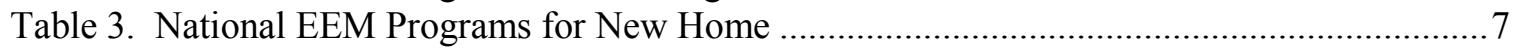

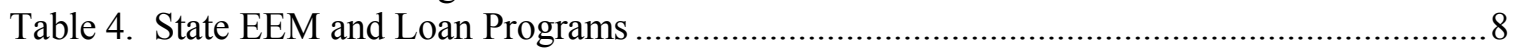

Table 5. Ratings Completed in Pilot States (By Calendar Year) ................................................. 12

Table 6. Number of Homes Nationwide Certified as ENERGY STAR Homes ...........................17

\section{List of Figures}

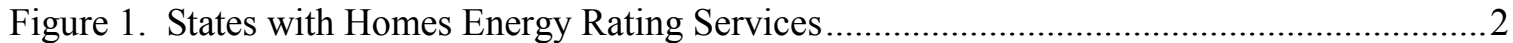

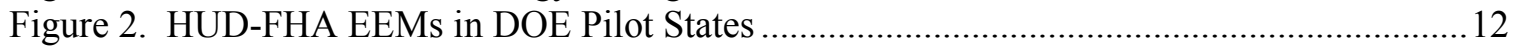

Figure 3. HUD FHA EEMs during Fiscal Years 1994-1998 _....................................................... 16

\section{Acknowledgements}

The research on which this report is based was conducted and managed at the National Renewable Energy Laboratory (NREL). This work was funded by the U.S. Department of Energy (DOE). The cognizant DOE program managers for this effort are David Boomsma and Michael McCabe.

The author would like to thank several researchers who contributed to this report: John Bonitz, NREL; Susan Conway, NREL; Barbara Farhar, NREL; and Ron Judkoff, NREL. I would also like to thank the people whose names appear in an appendix for their contributions and cooperation, which made this report possible. Many thanks for your time and effort.

The author would also like to thank the following reviewers, who provided numerous helpful comments and suggestions: Mark Ginsberg, DOE; David Boomsma, DOE; Michael McCabe, DOE; David Lee, EPA; Robert Groberg, HUD; Virginia Holman, HUD; Patricia O’Loughlin, Fannie Mae; John Hemschoot, Freddie Mac; Ron Judkoff, NREL; Barbara Farhar, NREL; John Bonitz, NREL; and John Reese. Special thanks are expressed to Kyra Epstein for editing this report; Wanda Addison and Nikki Kelly for assisting with report formatting; Erica Henningsen for working with contributors on text approvals; and Cluster Myers and Leslee Pohle for completing the word processing. 


\section{Acronyms}

\begin{tabular}{|c|c|}
\hline AHFC & Alaska Housing Finance Corporation \\
\hline BEES & Building Energy Efficiency Standards \\
\hline BESTEST & Building Energy Simulation Test \\
\hline BOP & Builder Option Package \\
\hline $\mathrm{CABO}$ & Council of American Building Officials \\
\hline $\mathrm{CEC}$ & California Energy Commission \\
\hline CHEERS & California Home Energy Rating System \\
\hline CHFA & Colorado Housing Finance Agency \\
\hline CHUMS & Computerized Housing Underwriting Management System \\
\hline $\mathrm{CY}$ & Calendar Year \\
\hline DOE & U.S. Department of Energy \\
\hline EEI & Edison Electric Institute \\
\hline EEIRR & Energy Efficiency Interest Rate Reduction \\
\hline EEMs & Energy-efficient mortgages \\
\hline EIM & Energy improvement mortgages \\
\hline EPA & U.S. Environmental Protection Agency \\
\hline EPACT & Energy Policy Act of 1992 \\
\hline ERHA & Energy Rated Homes of America \\
\hline ERH-AK & Energy Rated Homes of Alaska \\
\hline ERH-AR & Energy Rated Homes of Arkansas \\
\hline ERHC & Energy Rated Homes of Colorado \\
\hline ERHM & Energy Rated Homes of Mississippi \\
\hline ERH-VT & Energy Rated Homes of Vermont \\
\hline EWG & Evaluation Working Group \\
\hline FHA & Federal Housing Authority, HUD \\
\hline FSEC & Florida Solar Energy Center \\
\hline FY & Fiscal Year \\
\hline HELP & Home Energy Loan Program \\
\hline HERS & Home Energy Rating Systems \\
\hline HUD & U.S. Department of Housing and Urban Development \\
\hline MEC & Model Energy Code \\
\hline NAHB & National Association of Home Builders \\
\hline NASEO & National Association of State Energy Officials \\
\hline N-HERO & National Home Energy Resources Organization \\
\hline NREL & National Renewable Energy Lab \\
\hline $\mathrm{OEC}$ & Colorado Office of Energy Conservation \\
\hline PG\&E & Pacific Gas and Electric Company \\
\hline PVE & Petroleum Violation Escrow Funds \\
\hline PWG & Pilot States Working Group \\
\hline RESNET & Residential Energy Services Network \\
\hline RHS & Rural Housing Service, USDA \\
\hline RMS & Rating Management Software \\
\hline SEO & State Energy Office \\
\hline SEP & State Energy Program \\
\hline TVA & Tennessee Valley Authority \\
\hline USDA & U.S. Department of Agriculture \\
\hline VA & U.S. Department of Veterans Affairs \\
\hline V-HERO & Virginia Home Energy Rating Organization \\
\hline
\end{tabular}


VEIC

VHFA

WSU

YESS
Vermont Energy Investment Corporation

Vermont Housing Finance Agency

Washington State University

Yearly Energy Savings System Mortgage Program (Vermont) 


\section{Executive Summary}

Home Energy Ratings Systems (HERS) provide a standardized method of rating the energy efficiency of residential buildings. With this rating, homeowners and potential homebuyers can assess valuable information on the cost of energy and the potential for improving the efficiency of a home. A rating can also be the basis for qualifying for an energy-efficient mortgage (EEM).

The Energy Policy Act of 1992 included several provisions promoting the use of HERS and EEMs, which strengthened efforts to develop a national infrastructure for HERS and to promote the use of EEMs. This report documents HERS and EEMs activities since 1992 by the U.S. Department of Energy, the U.S.

Environmental Protection Agency, the U.S. Department of Housing and Urban Development, mortgage lenders, and other organizations. Efforts of the prime stakeholders have included, among other things:

- Regulatory actions - including draft guidelines for HERS

- Technical assistance - including training and validation of rating tools

- Promotional programs - such as mortgage rate reductions and increased loan amounts

- Funding for pilot state initiatives - to identify and overcome barriers.

Though the process of establishing HERS has faced some barriers, this report shows that, as of November 1999, home energy ratings were available in 47 states and the District of Columbia, which represents a significant increase from 1993 when home energy ratings were available in 17 states. Both national and state organizations have developed HERS and related residential energy-efficiency programs.

The availability and use of EEMs has also increased significantly. The number of EEMs supported by the Federal Housing Administration has increased more than eight times in the last three years. More than $\$ 2.5$ billion in federally supported EEMs have been issued to date. Several national lenders offer EEMs, and six states have state-specific EEM or loan programs. EEMs have been used to finance energyefficient homes in every state. 


\section{Introduction}

Improving the energy efficiency of the U.S. housing stock can result in significant benefits for homeowners, the economy, and the environment. Housing affordability can improve if borrowers can take advantage of a variety of energy-efficient mortgage products available, and lenders and secondary mortgages can make more loans. Builders can build houses and market them as energy efficient - thus increasing their market share. Real estate professionals can increase their commissions by selling houses that have the additional energy-efficient features. Becoming a trained and certified home energy rater can be an additional valuable skill for someone already in the residential building business. Contractors for energy-efficient equipment, and the manufacturers and distributors of that equipment, benefit from increased market share. Citizens and the environment benefit from a reduction in emissions from power plants and fossil fuel combustion from the resultant increase energy efficiency in housing.

A variety of laws, regulations, and policies have been or are being implemented to increase energy efficiency in the U.S. housing market. Section 102 of Energy Policy Act of 1992 (EPACT) amends Title II of the National Energy Conservation Policy Act (42 U.S. 8211 et. seq.) to promote the use of home energy ratings. This report, the National Status of HERS and EEMs, documents home energy rating systems (HERS) and energy-efficient mortgages (EEMs) activities over the past five years by the U.S. Department of Energy (DOE), the U.S. Environmental Protection Agency (EPA), the U.S. Department of Housing and Urban Development (HUD), and other organizations, banks, and companies. This report also documents the current status of HERS and EEMs in the marketplace. Sources include articles published in trade press and other media, press releases, programmatic information available in the public domain, and data reported to DOE.

A HERS is a standardized system for rating the energy efficiency of residential buildings. The home energy rating is a standard measurement of a home's energy efficiency, which allows a homebuyer to compare the energy efficiency of different homes. A homeowner who wants to upgrade the home's energy efficiency can use the energy rating to evaluate specific, cost-effective improvements. Most home energy ratings include an on-site inspection of a home by a residential energy efficiency professional - a home energy rater. Home energy raters are typically trained and certified by the operating HERS.

Often, home energy raters have worked in the housing or energy fields and include home inspectors, appraisers, energy auditors, low-income weatherization contractors, and energy-efficient homebuilders and designers. The home energy rater inspects the home and measures its energy characteristics, such as insulation levels, window efficiency, wall-to-window ratios, heating and cooling system efficiency, solar orientation of the home, and the efficiency of the water heating system. Diagnostic testing, such as using a blower door for air leakage and testing for duct leakage, is often part of the rating. For most HERS, the measurements are then entered into a computer program that produces a report of the cost-effective options for improving the home's energy efficiency as well a "rating" of the home's energy efficiency and estimated energy costs.

An EEM is any home mortgage for which either the underwriting guidelines have been relaxed specifically for energy-efficiency features, or for which any form of financing incentive is given for energy efficiency. Several lenders that offer EEMs require that a home energy rating be performed to verify that the energy efficiency of the home warrants an EEM. 


\section{Background}

In 1993, home energy ratings were only available in 17 states. ${ }^{1}$ As of November 1999, home energy ratings are available in 47 states and the District of Columbia, although the number of raters varies from state to state. Both national and state organizations have developed HERS and related residential energyefficiency programs, shown in Figure 1 and listed in Table 1. Several HERS provider pilot states are now offering ratings on a regional basis. Also, 11 independent HERS programs were operating as of September 1999, some of which have more than one state as their service territory.

Overall, several national lenders offer EEMs and six states have state-specific EEM or loan programs. EEMs have been used to finance energy-efficient homes in every state. Lists of EEM providers are shown in tables 2,3 and 4.

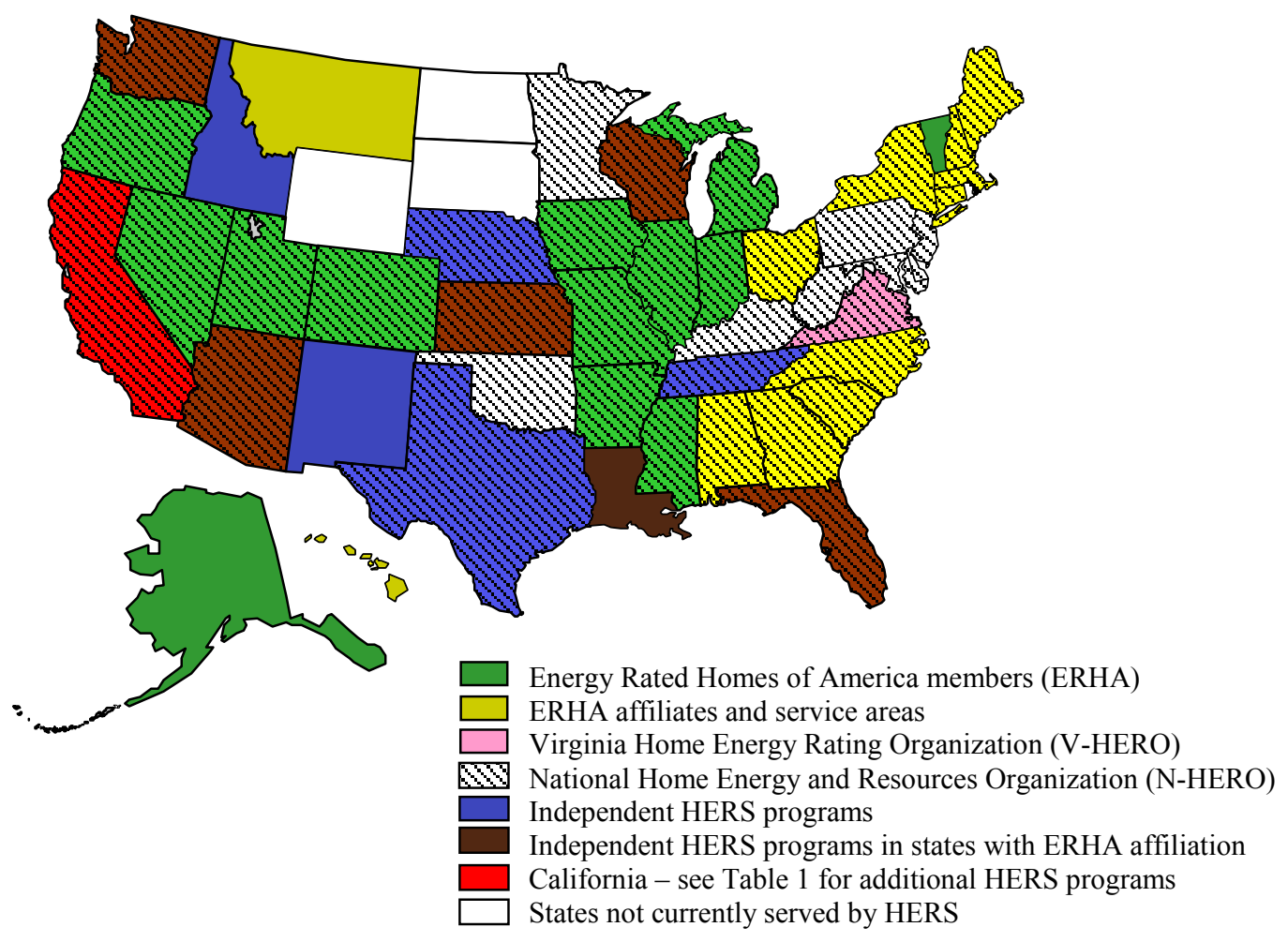

Figure 1. States with Home Energy Rating Services ${ }^{2}$

\footnotetext{
${ }^{1}$ The 17 states with home energy ratings in 1993 were: Alaska, Arizona, Arkansas, California, Colorado, Illinois, Indiana, Iowa, Louisiana, Michigan, Mississippi, New Mexico, Rhode Island, Texas, Vermont, Virginia, and West Virginia. Farhar, B.C., J. Eckert, 1993.

${ }^{2}$ Access to raters varies widely from state to state, i.e. some states have one or two raters and other states have 25 - 50 raters (see Table 1 for additional information and independent HERS program availability).
} 
Table 1. HERS and Other Residential Energy-Efficiency Programs, as of Fall 1999

\begin{tabular}{|c|c|c|c|}
\hline Organization/Program & Availability & Program Energy-Efficiency Scale & $\begin{array}{l}\text { Verification } \\
\text { Methodology }\end{array}$ \\
\hline $\begin{array}{l}\text { Energy Rated Homes of } \\
\text { America (ERHA)/Various } \\
\text { programs }\end{array}$ & See Figure 1. & $\begin{array}{l}\text { Numerical score of } 1-100 \text { where } 80 \\
\text { is equivalent to Model Energy Code } \\
1992\left(\text { MEC } 92^{4}\right) \text {. }\end{array}$ & Rating \\
\hline $\begin{array}{l}\text { National Home Energy \& } \\
\text { Resources Organization } \\
\text { (National-HERO)/HERS }\end{array}$ & See Figure 1. & $\begin{array}{l}\text { Numerical score of } 1-100 \text { where } 80 \\
\text { is equivalent to MEC } 92 .\end{array}$ & Rating \\
\hline $\begin{array}{l}\text { Alaska Housing Finance } \\
\text { Corporation (AHFC)/AHFC } \\
\text { Energy Programs }^{6}\end{array}$ & Alaska only. & $\begin{array}{l}\text { Numerical score of } 1-100 \text { where } 80 \\
\text { is equivalent to MEC } 92 .\end{array}$ & Rating \\
\hline $\begin{array}{l}\text { Arizona / Southwest Gas } \\
\text { Corporation }\end{array}$ & Arizona only. & $\begin{array}{l}\text { Numerical score of } 1-100 \text { where } 80 \\
\text { is equivalent to MEC } 95 .\end{array}$ & $\begin{array}{l}\text { Ratings performed } \\
\text { by utility company } \\
\text { and builders. }\end{array}$ \\
\hline $\begin{array}{ll}\text { California Organizations: }{ }^{9} \\
\text { - } & \text { CEMCO } \\
\text { - } & \text { CHEERS (ERHA Affiliate) } \\
\text { - } & \text { ConSol, Inc. } \\
\text { - } & \text { EEMs, Inc. } \\
\text { - } & \text { Federal Energy Services } \\
\text { - } & \text { H\&L Energy Savers } \\
& \text { Rated Energy Plus }\end{array}$ & California only. & $\begin{array}{l}\text { Title } 24 \text { - Building Energy Efficiency } \\
\text { Standards (BEES), which has been } \\
\text { certified to be more stringent than } \\
\text { MEC } 95 .{ }^{10}\end{array}$ & $\begin{array}{l}\text { Rating or } \\
\text { professional } \\
\text { consultation using } \\
\text { state-certified } \\
\text { analysis software; } \\
\text { depending on site } \\
\text { specifics, could be } \\
\text { either prescriptive or } \\
\text { performance based. }\end{array}$ \\
\hline $\begin{array}{l}\text { Florida Department of } \\
\text { Community Affairs / Florida } \\
\text { Program } 11\end{array}$ & Florida only. & $\begin{array}{l}\text { Numerical score of } 1-100 \text { where } 80 \\
\text { is equivalent to MEC } 92 .\end{array}$ & Rating \\
\hline
\end{tabular}

\footnotetext{
${ }^{3}$ ERHA-affiliated programs include: Energy Rated Homes of Alaska, Energy Rated Homes of Arkansas (Arkansas and Missouri), Energy Rated Homes of Colorado, CHEERS (one of several California HERS providers), Energy Rated Homes of Iowa, Energy Rated Homes of Louisiana, Energy Rated Homes of the Midwest (Indiana and Michigan), Energy Rated Homes of Mississippi, Energy Rated Homes of Nevada, Energy Rated Homes of Oregon, Energy Rated Homes of the South (Alabama, Georgia, North Carolina, and South Carolina), Energy Rated Homes of Utah, Energy Rated Homes of Vermont, Energy Wise Homes of Illinois, Florida Energy Gauge Program, and Wisconsin Energy Conservation Corporation. From Energy Rated Homes web site, http://www.erha.com. Date accessed: August 27, 1999. Other ERHA-affiliated states include: Connecticut, Maine, Massachusetts, Montana, New Hampshire, New York, and Ohio. E-mail from Steve Baden, RESNET, November $18,1999$.

${ }^{4}$ MEC (Model Energy Code): “A 'model' national standard for residential energy efficiency. The MEC was developed through a national consensus process by the Council of American Building Officials (CABO) and is the accepted national minimum efficiency standard for residential construction. Since MEC is a model code, it does not have the "force of law" unless and until it is adopted by the local code authority. Nonetheless, MEC is used as the basis for many, if not most, of the energy-efficiency criteria employed in the U.S. marketplace. By virtue of its reference in EPACT, the MEC is used as the national standard for determining EEM qualification, and it serves as the national 'reference point' used by HERS in the determination of energy ratings for homes." From the Florida Solar Energy Center web site, http://www.fsec.ucf.edu/ratings/e_terms.htm. Date accessed: December 6, 1999. The International Code Council (ICC) was established by $\mathrm{CABO}$ and other code organizations, and ICC is maintaining the International Energy Conservation Code (IECC), the successor to the MEC. ${ }^{5}$ National Home Energy \& Resources Organization, Inc. has raters in Alabama, Arkansas, Arizona, California, Colorado, Connecticut, Delaware, Florida, Georgia, Illinois, Indiana, Iowa, Kansas, Kentucky, Maine, Maryland, Massachusetts, Michigan, Minnesota, Mississippi, Missouri, Nebraska, Nevada, New Hampshire, New Jersey, New York, North Carolina, Ohio, Oklahoma, Oregon, Pennsylvania, Rhode Island, South Carolina, Tennessee, Texas, Utah, Virginia, Washington, and West Virginia. The number of raters per state varies widely. http://www.nationalhero.com. Date accessed: November 11, 1999.

${ }^{6}$ Conversation with Phil Kaluza, Alaska Housing Finance Corporation Energy Program, April 23, 1999.

${ }^{7}$ Conversation with Eric Shoberg, Southwest Gas Corporation, March 2, 2000. Tucson Electric Power also has an active residential energyefficiency program in Arizona, however this program does not use ratings. Instead, a field test determines the efficiency of a home. Conversation with Randy Altergott, Tucson Electric Power, March 8, 2000.

${ }^{8}$ Utility company performs ratings on building plans; builder's ratings are based on field testing of the homes. Conversation with Eric Shoberg, Southwest Gas Corporation, March 2, 2000.

${ }^{9}$ Conversation and correspondence with Mike Hodgson, ConSol Inc., August, 1999.

${ }^{10}$ Letter from California Energy Commission (CEC), December 22, 1998 to Dan Reicher, DOE, which states that "the Efficiency Standards Committee of the CEC hereby certifies that California's Building Energy Efficiency Standards (Title 24, Part 6) for Residential Buildings achieves greater energy efficiency than [MEC 95].”

${ }^{11}$ Correspondence with Philip Fairey, Florida Solar Energy Center, August 1999.
} 
Table 1. HERS and Other Residential Energy-Efficiency Programs, as of Fall 1999 (continued)

\begin{tabular}{|c|c|c|c|}
\hline Organization/Program & Availability & Program Energy-Efficiency Scale & $\begin{array}{l}\text { Verification } \\
\text { Methodology }\end{array}$ \\
\hline $\begin{array}{l}\text { Idaho State Energy Office / } \\
\text { GEMSTAR Program }{ }^{12} \\
\text { (See Table } 4 \text { for financing } \\
\text { criteria.) }\end{array}$ & Idaho only. & $\begin{array}{l}\text { One-star to five-star rating scale } \\
\text { where a five-star rating is equivalent } \\
\text { to } 30 \% \text { more efficient than MEC } 92 \text {. } \\
\text { New site-built and manufactured } \\
\text { homes require a five-star rating. }\end{array}$ & Rating \\
\hline $\begin{array}{l}\text { Kansas Department of } \\
\text { Commerce \& Housing/ } \\
\text { Kansas Energy Star Program }{ }^{13}\end{array}$ & $\begin{array}{l}\text { Kansas, } \\
\text { Arkansas, } \\
\text { Nebraska, } \\
\text { New York, and } \\
\text { Missouri. }{ }^{14}\end{array}$ & $\begin{array}{l}\text { Numerical score of } 1-100 \text { where } 80 \\
\text { is equivalent to MEC } 92 .\end{array}$ & Rating \\
\hline $\begin{array}{l}\text { Louisiana State Energy Office / } \\
\text { Louisiana Home Energy Loan } \\
\text { Program (HELP) } \\
\text { (See Table } 4 \text { for financing } \\
\text { criteria.) }\end{array}$ & $\begin{array}{l}\text { Louisiana } \\
\text { only. }\end{array}$ & $\begin{array}{l}\text { One to five star rating scale where } \\
\text { a five star rating is equivalent to } \\
30 \% \text { more efficient than MEC } 92 \text {. } \\
\text { Energy-efficient financing-new } \\
\text { homes require a Five Star rating; } \\
\text { existing homes require } 30 \% \text { energy } \\
\text { efficiency improvement. }\end{array}$ & Rating \\
\hline $\begin{array}{l}\text { Nebraska State Energy Office/ } \\
\text { Nebraska Program }{ }^{16} \\
\text { (See Table } 4 \text { for financing } \\
\text { criteria.) }\end{array}$ & $\begin{array}{l}\text { Nebraska } \\
\text { only. }\end{array}$ & $\begin{array}{l}\text { Numerical score of } 1-100 \text { where } \\
80 \text { is equivalent to } 1995 \mathrm{MEC} \text {. }\end{array}$ & Rating \\
\hline $\begin{array}{l}\text { New Mexico/Green Builder } \\
\text { Program }^{17}\end{array}$ & $\begin{array}{l}\text { New Mexico } \\
\text { only. }\end{array}$ & $\begin{array}{l}\text { Numerical score of 1-100 where } \\
80 \text { is equivalent to MEC 92; also } \\
\text { requires certain prescribed green } \\
\text { building features. }\end{array}$ & $\begin{array}{l}\text { Self-certified } \\
\text { ratings and } \\
\text { sampled ratings } \\
\text { performed by utility } \\
\text { companies, } \\
\text { builders and } \\
\text { developers. }\end{array}$ \\
\hline $\begin{array}{l}\text { Tennessee Valley Authority } \\
\text { (TVA) /energy right } t^{\mathbb{Q}} \text { Residential } \\
\text { New Homes Program } \\
\text { - energy right certification } \\
\text { requires four stars or a rating } \\
\text { of } 80 \text { to } 82 \text {. } \\
\text { - energy right gold } \\
\quad \text { certification requires } 4 \frac{1}{2} \text { to } 5 \\
\text { stars or a rating of } 83 \text { or } \\
\text { better. }\end{array}$ & $\begin{array}{l}\text { Tennessee } \\
\text { and adjacent } \\
\text { states } \\
\text { (including } \\
\text { portions of } \\
\text { AL, GA, KY, } \\
\text { MS, NC, and } \\
\text { VA). }\end{array}$ & $\begin{array}{l}\text { Numerical score of } 1-100 \text { where } \\
80 \text { is equivalent to MEC } 92 \text {. } \\
\text { Scores are correlated to a five star } \\
\text { rating scale. }\end{array}$ & $\begin{array}{l}\text { Verification } \\
\text { method is a } \\
\text { combination of a } \\
\text { performance } \\
\text { rating, physical } \\
\text { inspection, and } \\
\text { builder affidavit. } \\
\text { All program- } \\
\text { certified homes } \\
\text { must be inspected } \\
\text { by a TVA- } \\
\text { authorized } \\
\text { professional. }\end{array}$ \\
\hline $\begin{array}{l}\text { Texas State Energy } \\
\text { Commission/ Texas Program²0 }\end{array}$ & $\begin{array}{l}\text { Texas only. } \\
\text { (Pilot) }\end{array}$ & $\begin{array}{l}\text { Numerical score of } 1-100 \text { where } \\
80 \text { is equivalent to MEC } 92 .\end{array}$ & Rating \\
\hline
\end{tabular}

\footnotetext{
${ }^{12}$ Conversation with Ken Eklund, Idaho Department of Water Resources, Energy Division, June 16, 1999.

${ }^{13}$ Conversation with Stan Butler, Kansas Department of Commerce and Housing, Energy Programs Section, June 17, 1999.

${ }^{14}$ The Kansas Energy Star program is currently negotiating with Colorado, North Dakota, and Wyoming for a variety of cooperative or reciprocal arrangements.

${ }^{15}$ Correspondence with Wade Byrd, Louisiana Department of Natural Resources, Energy Division, September $27,1999$.

${ }^{16}$ Conversation with Jack Osterman, Nebraska Energy Office, September 15, 1999.

${ }^{17}$ Conversation with Harold Trujillo, New Mexico Energy Conservation and Management Division, May 18, 1999.

${ }^{18}$ Conversation with Jim Folkman, Home Builders Association of Central New Mexico (HBA of CNM), October 1, 1999.

${ }^{19}$ Conversation with Jerry Lyle, Tennessee Valley Authority, September 17, 1999.

${ }^{20}$ Conversation with Felix Lopez, Texas General Services Commission, Energy Conservation Office, August $11,1999$.
} 
Table 1. HERS and Other Residential Energy-Efficiency Programs, as of Fall 1999 (continued)

\begin{tabular}{|l|l|l|l|}
\hline $\begin{array}{l}\text { Virginia Home Energy Rating } \\
\text { Organization (V-HERO)/HERS }\end{array}$ & Virginia only. & $\begin{array}{l}\text { Numerical score of 1-100 where } \\
80 \text { is equivalent to MEC } 92 .\end{array}$ & Rating \\
\hline $\begin{array}{l}\text { Washington State University } \\
\text { (WSU) Cooperative Extension } \\
\text { Energy Program }\end{array}$ & $\begin{array}{l}\text { Washington } \\
\text { only. }\end{array}$ & $\begin{array}{l}\text { Numerical score of 1-100 where } 80 \\
\text { is equivalent to MEC } 92 .\end{array}$ & Rating \\
\hline $\begin{array}{l}\text { Wisconsin Energy } \\
\text { Conservation Corporation/ }\end{array}$ & $\begin{array}{l}\text { Wisconsin and } \\
\text { parts of } \\
\text { Minnesota. }\end{array}$ & $\begin{array}{l}\text { Numerical score of 1-100, where } 80 \\
\text { is equivalent to MEC 92. New } \\
\text { construction homes with a score of } \\
86 \text { or higher qualify for an EEM. } \\
\text { Existing homes with a score of } 70 \text { or } \\
\text { higher qualify for an energy } \\
\text { improvement mortgage. }\end{array}$ & Rating \\
& & & \\
\hline
\end{tabular}

Table 2. National EEM Programs for Existing Homes

\begin{tabular}{|c|c|c|c|c|}
\hline $\begin{array}{c}\text { Organization/ } \\
\text { Program }\end{array}$ & $\begin{array}{l}\text { Energy- } \\
\text { Efficiency } \\
\text { Criteria }\end{array}$ & Availability & $\begin{array}{c}\text { Program } \\
\text { Energy- } \\
\text { Efficiency Scale }\end{array}$ & Verification Methodology \\
\hline $\begin{array}{l}\text { HUD-FHA / } \\
\text { 203(b) EEM, } \\
\text { 203(k) EEM, } \\
234 \text { EEM, } \\
\text { And 221(d2) } \\
\text { EEM. }^{25}\end{array}$ & $\begin{array}{l}\text { Federal Housing } \\
\text { Administration } \\
\text { (FHA) guidelines } \\
\text { require } \\
\text { determination of } \\
\text { cost } \\
\text { effectiveness. }^{26}\end{array}$ & $\begin{array}{l}\text { The total cost of } \\
\text { the } \\
\text { improvements } \\
\text { (including } \\
\text { maintenance } \\
\text { costs) must } \\
\text { pass a net } \\
\text { present value } \\
\text { test of energy } \\
\text { costs saved } \\
\text { over the lifetime } \\
\text { of the } \\
\text { improvements. }\end{array}$ & $\begin{array}{l}\text { Cost effectiveness } \\
\text { calculations must } \\
\text { be documented by } \\
\text { a HERS rating } \\
\text { report. }\end{array}$ & $\begin{array}{l}\text { EEM enhancements for financing of } \\
\text { energy-efficiency improvements to } \\
\text { existing homes can be added to any of } \\
\text { the following HUD-FHA mortgages; } \\
203(\mathrm{~b}), 203(\mathrm{k}), 203(\mathrm{~h}), 234 \text { [for } \\
\text { condominiums], or } 221(\mathrm{~d} 2) \text {, for either } \\
\text { purchase or refinance of a property. } \\
\text { The property does not need to be } \\
\text { appraised for the value of the energy- } \\
\text { efficiency improvements. The } \\
\text { borrower does not have to undergo } \\
\text { qualification for the additional amount } \\
\text { of financing of an EEM. No additional } \\
\text { down payment is required on the } \\
\text { additional financing. The limits of the } \\
\text { amount of financing allowed are the } \\
\text { same as other HUD-FHA financing: } \\
\text { e.g., for existing single-family homes, } \\
\text { HUD-FHA will underwrite an increase } \\
\text { in the loan amount for the greater of } \\
\$ 4,000 \text { or } 5 \% \text { of the appraised value } \\
\text { (with a cap of } \$ 8,000) \text {. }\end{array}$ \\
\hline
\end{tabular}

\footnotetext{
${ }^{21}$ Conversation and correspondence with Stephen Lowrie, National HERO, October 10, 1999.

${ }^{22}$ In performing ratings on new homes and manufactured housing, the WSU Cooperative Extension Energy Program has used customized software that is based on the state's Model Conservation Code, a predecessor to CABO MEC. Conversation with Bruce Carter, WSU Cooperative Extension Energy Service, October 15, 1999.

${ }^{23} \mathrm{http}: / /$ weccusa.org/Home\%20Performance/Home\%20Page.htm. Date accessed, March 14, 2000.

${ }^{24}$ Conversation with Mary Meunier, Wisconsin Energy Bureau, March 14, 2000.

${ }^{25}$ Conversation and correspondence with Virginia Holman, HUD-FHA, August 17, 1999.

${ }^{26}$ HUD-FHA guidelines for existing home EEMs do not involve MEC. This is because for most existing homes, energy-efficiency improvements that would meet MEC 92 would be cost prohibitive.
} 
Table 2. National EEM Programs for Existing Homes (continued)

\begin{tabular}{|c|c|c|c|c|}
\hline $\begin{array}{c}\text { Organization/ } \\
\text { Program }\end{array}$ & $\begin{array}{c}\text { Energy-Efficiency } \\
\text { Criteria }\end{array}$ & Availability & $\begin{array}{l}\text { Program Energy- } \\
\text { Efficiency Scale }\end{array}$ & Verification Methodology \\
\hline $\begin{array}{l}\text { Department of } \\
\text { Veterans } \\
\text { Affairs (VA) / } \\
\mathrm{EEM}^{27}\end{array}$ & $\begin{array}{l}\text { Acceptable energy- } \\
\text { efficiency } \\
\text { improvements are } \\
\text { prescribed in the VA } \\
\text { guidelines. Other } \\
\text { improvements may } \\
\text { be accepted at } \\
\text { lender's discretion } \\
\text { (e.g., insulation, } \\
\text { water heaters, storm } \\
\text { windows/doors, } \\
\text { weather-stripping, } \\
\text { solar or conventional } \\
\text { heating/cooling } \\
\text { systems.) }\end{array}$ & $\begin{array}{l}\text { The total cost of } \\
\text { the } \\
\text { improvements } \\
\text { (as defined by } \\
\text { the increase in } \\
\text { monthly } \\
\text { mortgage } \\
\text { payments) must } \\
\text { not exceed the } \\
\text { likely reduction } \\
\text { in monthly utility } \\
\text { costs. }\end{array}$ & $\begin{array}{l}\text { Loans for } \\
\text { improvements over } \\
\$ 3,000 \text { must be } \\
\text { deemed cost effective } \\
\text { by an official } \\
\text { documented } \\
\text { verification of the } \\
\text { improvements. }\end{array}$ & $\begin{array}{l}\text { VA allows the addition of } \$ 3,000 \\
\text { of improvements without } \\
\text { verification of the improvements. } \\
\text { Or VA allows up to } \$ 6,000 \text { for } \\
\text { energy improvements verified } \\
\text { and documented to be cost } \\
\text { effective by either of the following } \\
\text { means: } \\
\text { A) A HERS rating; or } \\
\text { B) a "local reliable information } \\
\text { source" subject to lender's } \\
\text { determination. }\end{array}$ \\
\hline $\begin{array}{l}\text { Fannie Mae/ } \\
\text { EEM (June } \\
1999)^{28}\end{array}$ & Not Applicable. & $\begin{array}{l}\text { Annual energy } \\
\text { savings must } \\
\text { exceed the } \\
\text { annual } \\
\text { additional } \\
\text { mortgage cost. } \\
\text { Savings are } \\
\text { calculated from } \\
\text { baseline of "as } \\
\text { is condition." }\end{array}$ & $\begin{array}{l}\text { Scientific ratings or } \\
\text { preapproved } \\
\text { prescriptive programs } \\
\text { including HERS and } \\
\text { sampled ratings. }\end{array}$ & $\begin{array}{l}\text { Expands features of the prior } \\
\text { Fannie Mae EEM to allow: } 100 \% \\
\text { financing of energy } \\
\text { improvements, new definition of } \\
\text { cost effectiveness, combination } \\
\text { with other Fannie Mae mortgage } \\
\text { products, for new or existing one- } \\
\text { to four-family properties, for } \\
\text { purchase or refinance. Costs of } \\
\text { improvements cannot exceed } \\
15 \% \text { of property's value, and final } \\
\text { loan-to-value ratio cannot exceed } \\
95 \% \text {. }\end{array}$ \\
\hline $\begin{array}{l}\text { Freddie } \\
\text { Mac/EEM }^{29}\end{array}$ & $\begin{array}{l}\text { Documented } \\
\text { determination of } \\
\text { "high efficiency" } \\
\text { using either; A) } \\
\text { HERS rating, B) } \\
\text { energy consultant's } \\
\text { certification, C) } \\
\text { appraisal of } \\
\text { improvements, or D) } \\
\text { MEC } 92 \text { compliance. }\end{array}$ & Not Applicable. & $\begin{array}{l}\text { Documentation of } \\
\text { high efficiency: A) } \\
\text { HERS rating report; } \\
\text { B) Form } 70 \mathrm{~A}^{30} \\
\text { certified by an energy } \\
\text { consultant; C) an } \\
\text { appraisal report } \\
\text { indicating the post- } \\
\text { improvement energy } \\
\text { efficiency of the } \\
\text { property; or D) MEC } \\
92 \text { compliance } \\
\text { documented by one } \\
\text { of the following; a) } \\
\text { building permit in } \\
\text { states with mandatory } \\
\text { state energy code, b) } \\
\text { preapproved } \\
\text { prescriptive } \\
\text { certification, c) } \\
\text { assurance from an } \\
\text { energy consultant or } \\
\text { a builder. }\end{array}$ & $\begin{array}{l}\text { Allows both front-end and back- } \\
\text { end debt-to-income ratios to be } \\
\text { stretched by the amount of the } \\
\text { expected savings. Alternatively, } \\
\text { allows lender to increase the } \\
\text { borrower's maximum monthly } \\
\text { mortgage payment by the } \\
\text { amount of the expected monthly } \\
\text { energy savings. Freddie Mac } \\
\text { has no specific limits on the } \\
\text { amounts of their EEMs, other } \\
\text { than final loan-to-value ratio, } \\
\text { which is the same as their } \\
\text { regular mortgage loans. }\end{array}$ \\
\hline
\end{tabular}

${ }^{27}$ Conversation and correspondence with Bob Finneran, Department of Veterans Affairs, August, 1999.

${ }^{28}$ Conversation and correspondence with Patricia O’Loughlin, Fannie Mae, August, 1999.

${ }^{29}$ Conversation and correspondence with John Hemschoot, Freddie Mac, August 17, 1999. 
Table 3. National EEM Programs for New Homes

\begin{tabular}{|c|c|c|c|c|}
\hline $\begin{array}{l}\text { Organization/ } \\
\text { Program }\end{array}$ & $\begin{array}{l}\text { Energy- } \\
\text { Efficiency } \\
\text { Criteria }\end{array}$ & $\begin{array}{c}\text { Cost- } \\
\text { Effectiveness } \\
\text { Criteria }\end{array}$ & Verification & Terms \& Conditions \\
\hline $\begin{array}{l}\text { HUD-FHA / } \\
\text { 203(b) EEM, } \\
\text { 203(h) EEM, } \\
234 \text { EEM, } \\
\text { and 221(d2) } \\
\text { EEM. }^{31}\end{array}$ & $\begin{array}{l}\text { Must exceed } \\
\text { MEC } 92 .\end{array}$ & $\begin{array}{l}\text { The total cost } \\
\text { of the energy- } \\
\text { efficiency } \\
\text { features } \\
\text { (including } \\
\text { maintenance } \\
\text { cost) must } \\
\text { pass a net } \\
\text { present value } \\
\text { test of energy } \\
\text { costs saved } \\
\text { over the } \\
\text { lifetime of the } \\
\text { features. }\end{array}$ & $\begin{array}{l}\text { Cost-effectiveness } \\
\text { calculations must be } \\
\text { documented by a } \\
\text { HERS rating report } \\
\text { showing attainment of a } \\
\text { rating of } 81 \text { or higher - } \\
\text { indicating greater } \\
\text { efficiency than MEC } 92 \text {. }\end{array}$ & $\begin{array}{l}\text { EEM enhancements for financing } \\
\text { of energy-efficiency features in new } \\
\text { homes can be added to any of the } \\
\text { following HUD-FHA mortgages; } \\
203(\mathrm{~b}), 203(\mathrm{~h}), 234 \text { [for } \\
\text { condominiums], or } 221(\mathrm{~d} 2) \text {. The } \\
\text { property does not need to be } \\
\text { appraised for the value of the } \\
\text { energy-efficiency improvements. } \\
\text { The borrower does not have to } \\
\text { undergo qualification for the } \\
\text { additional amount of financing of an } \\
\text { EEM. No additional down payment } \\
\text { is required on the additional } \\
\text { financing. The limits of the amount } \\
\text { of financing allowed are the same } \\
\text { as other HUD-FHA financing: e.g., } \\
\text { for existing single-family homes, } \\
\text { HUD-FHA will underwrite an } \\
\text { increase in the loan amount for the } \\
\text { greater of } \$ 4,000 \text { or } 5 \% \text { of the } \\
\text { appraised value (with a cap of } \\
\$ 8,000 \text { ). }\end{array}$ \\
\hline $\begin{array}{l}\text { Fannie Mae/ } \\
\text { EEM (June } \\
1999)^{32}\end{array}$ & $\begin{array}{l}30 \% \text { or better } \\
\text { than MEC } 92 .\end{array}$ & $\begin{array}{l}\text { Annual energy } \\
\text { savings must } \\
\text { exceed the } \\
\text { annual } \\
\text { additional } \\
\text { mortgage cost. } \\
\text { Savings are } \\
\text { calculated } \\
\text { from baseline } \\
\text { of "as is } \\
\text { condition." }\end{array}$ & $\begin{array}{l}\text { Scientific ratings or } \\
\text { prescriptive programs } \\
\text { including HERS, } \\
\text { sampled ratings, and } \\
\text { preapproved } \\
\text { prescriptive measures. }\end{array}$ & $\begin{array}{l}\text { Expands features of the prior } \\
\text { Fannie Mae EEM to allow } 100 \% \\
\text { financing of energy improvements, } \\
\text { revised definition of cost } \\
\text { effectiveness from that of the prior } \\
\text { EEM, and combination with other } \\
\text { Fannie Mae mortgage products for } \\
\text { purchase or refinance of new or } \\
\text { existing one- to four-family } \\
\text { properties. Costs of improvements } \\
\text { cannot exceed } 15 \% \text { of property's } \\
\text { value, and final loan-to-value ratio } \\
\text { cannot exceed } 95 \% \text {. }\end{array}$ \\
\hline
\end{tabular}

\footnotetext{
${ }^{30}$ Freddie Mac's Form 70A is a two-part form (formerly the Energy Addendum to the Residential Appraisal Report), the first part of which must be completed by an energy consultant documenting their evaluation of the energy-efficiency features of the given home. Part two is not required for an EEM but may be completed by the appraiser or energy consultant documenting the calculated savings expected from the energy-efficiency features.

${ }^{31}$ Conversation and correspondence with Virginia Holman, August 17, 1999.

${ }^{32}$ Conversation and correspondence with Patricia O’Loughlin, August, 1999.
} 
Table 3. National EEM Programs for New Homes (continued)

\begin{tabular}{|c|c|c|c|c|}
\hline $\begin{array}{c}\text { Organization/ } \\
\text { Program }\end{array}$ & $\begin{array}{c}\text { Energy- } \\
\text { Efficiency } \\
\text { Criteria }\end{array}$ & $\begin{array}{c}\text { Cost- } \\
\text { Effectiveness } \\
\text { Criteria }\end{array}$ & Verification & Terms \& Conditions \\
\hline $\begin{array}{l}\text { Freddie Mac } \\
/ \text { EEM }^{33}\end{array}$ & $\begin{array}{l}\text { Improvements } \\
\text { must be } \\
\text { determined to } \\
\text { be high } \\
\text { efficiency by } \\
\text { means of } \\
\text { HERS, energy } \\
\text { consultant's } \\
\text { certification, or } \\
\text { MEC } 92 \\
\text { compliance. }\end{array}$ & $\begin{array}{l}\text { Freddie Mac } \\
\text { policies do not } \\
\text { require cost } \\
\text { effectiveness } \\
\text { criteria, per se. }\end{array}$ & $\begin{array}{l}\text { High efficiency must be } \\
\text { verified using either: } \\
\text { a) HERS report; b) } \\
\text { Form } 70 A \text { certified by } \\
\text { an energy consultant; } \\
\text { c) an appraisal report } \\
\text { indicating the energy } \\
\text { efficiency of the } \\
\text { property after the } \\
\text { improvements; or d) } \\
\text { MEC } 92 \text { compliance } \\
\text { documented by } \\
\text { mandatory state code, } \\
\text { label certification, an } \\
\text { energy consultant, or a } \\
\text { builder. }\end{array}$ & $\begin{array}{l}\text { Allows both front-end and back- } \\
\text { end debt-to-income ratios to be } \\
\text { stretched by the amount of the } \\
\text { expected savings. Alternatively, } \\
\text { allows lender to increase the } \\
\text { borrower's maximum monthly } \\
\text { mortgage payment by the amount } \\
\text { of the expected monthly energy } \\
\text { savings. Freddie Mac has no } \\
\text { specific limits on the amounts of } \\
\text { their EEMs, other than loan-to- } \\
\text { value ratio, which is the same as } \\
\text { their regular mortgage loans. }\end{array}$ \\
\hline
\end{tabular}

Table 4. State EEM and Loan Programs

\begin{tabular}{|c|c|c|c|}
\hline State/Program & $\begin{array}{c}\text { Energy-Efficiency } \\
\text { Criteria }\end{array}$ & $\begin{array}{c}\text { Energy- } \\
\text { Efficiency } \\
\text { Verification }\end{array}$ & Terms \& Conditions \\
\hline $\begin{array}{l}\text { Alaska Housing Finance } \\
\text { Corporation /Home Energy } \\
\text { Rating Program, based on } \\
\text { the Alaskan Building } \\
\text { Energy Efficiency Standard } \\
\text { (BEES) }\end{array}$ & $\begin{array}{l}\text { "Four Stars Plus," } \\
\text { equals a rating of } 83 \\
\text { or better (roughly } \\
25 \% \text { better than MEC } \\
92 \text { ). Five stars are } \\
\text { given for a rating of } \\
88 \text { or better (roughly } \\
50 \% \text { better than MEC } \\
92) .{ }^{35}\end{array}$ & Rating. & $\begin{array}{l}\text { Home buyers who obtain an AHFC loan } \\
\text { may qualify for an interest rate } \\
\text { reduction (up to } 1.5 \% \text { ) and/or } \\
\text { increased debt-income ratios, } \\
\text { depending on the energy efficiency of } \\
\text { the home. Both new and existing } \\
\text { homes are eligible. The financial } \\
\text { incentives are based on the energy } \\
\text { rating and whether the property has } \\
\text { access to natural gas (larger interest } \\
\text { rate reductions are given to homes } \\
\text { lacking natural gas access). }\end{array}$ \\
\hline $\begin{array}{l}\text { Energy Rated Homes of } \\
\text { Alaska/Energy Mortgage } \\
\text { Programs }\end{array}$ & $\begin{array}{l}\text { New construction- } \\
\text { Four Star Plus and } \\
\text { Five Star. } \\
\text { Existing homes-No } \\
\text { minimum required to } \\
\text { participate. }\end{array}$ & Rating. & $\begin{array}{l}\text { Home buyers qualify for closing cost } \\
\text { reductions and increased debt to } \\
\text { income ratios. Energy Efficiency Value } \\
\text { Increment (EEVI) for homes that } \\
\text { achieve a rating over } 85 \text { points (Four } \\
\text { Star Plus threshold). Incentives are } \\
\text { offered for both new and existing } \\
\text { homes. }\end{array}$ \\
\hline
\end{tabular}

\footnotetext{
${ }^{33}$ Conversation and correspondence with John Hemschoot, August 17, 1999.

${ }^{34}$ Conversation with Phil Kaluza, Alaska Housing Finance Corporation Energy Program, April 23, 1999.

${ }^{35}$ The Alaskan BEES was developed before MEC 1992, therefore this comparison of the two is only approximated. While there is no technical analysis comparing the two (as was done with California's Title 24 BEES and MEC 1992), due to climatic differences the Alaskan BEES is probably more rigorous than MEC 92.

${ }^{36}$ E-mail from Barbara Collins, Energy Rated Homes of Alaska, January, 5, 2000.
} 
Table 4. State EEM and Loan Programs (continued)

\begin{tabular}{|c|c|c|c|}
\hline State/Program & $\begin{array}{c}\text { Energy-Efficiency } \\
\text { Criteria }\end{array}$ & $\begin{array}{l}\text { Energy-Efficiency } \\
\text { Verification }\end{array}$ & Terms \& Conditions \\
\hline Idaho /GEMSTAR ${ }^{37}$ & $\begin{array}{l}\text { Five stars - } \\
30 \% \text { over MEC. }\end{array}$ & $\begin{array}{l}\text { Rating for new and } \\
\text { existing homes; } \\
\text { brand-certified } \\
\text { prescriptive } \\
\text { programs for } \\
\text { manufactured } \\
\text { homes (i.e., Super } \\
\text { Good Cents or } \\
\text { Natural Choice). }\end{array}$ & $\begin{array}{l}\text { Four percent interest loans of } \$ 1,000 \text { to } \\
\$ 1,500 \text { for certified manufactured } \\
\text { homes; }{ }^{38} \text { loans have five-year term and } \\
\text { are funded out of a state-subsidized } \\
\text { revolving loan fund. }\end{array}$ \\
\hline $\begin{array}{l}\text { Louisiana /Home } \\
\text { Energy Loan } \\
\text { Program }^{39}\end{array}$ & $\begin{array}{l}30 \% \text { over MEC } 1995, \\
\text { with greater incentives } \\
\text { for higher efficiency } \\
\text { (i.e., either a larger } \\
\text { loan at } 2 \% \text { interest or } \\
\text { a larger cash-at- } \\
\text { closing award). }\end{array}$ & Rating. & $\begin{array}{l}\text { For both new and existing homes HELP } \\
\text { offers either a) a } 2 \% \text { interest loan on the } \\
\text { energy-efficiency improvement portion of } \\
\text { the house, or b) a cash-at-closing } \\
\text { incentive of } 2 \% \text { of the purchase price } \\
\text { (limited to } \$ 1,000 \text { ). The value of these } \\
\text { financial incentives are set by the } \\
\text { "energy-efficient premium (EEP)." } \\
\text { The EEP is calculated differently for new } \\
\text { and existing homes. New: EEP is the } \\
\text { present value of energy savings over the } \\
\text { life of the loan. Existing: EEP is the } \\
\text { lesser of the cost of improvements or the } \\
\text { present value of the energy saved by the } \\
\text { improvements over their useful lives. } \\
\text { These incentives are funded from an } \\
\text { escrow revolving loan fund. }\end{array}$ \\
\hline $\begin{array}{l}\text { Nebraska /Nebraska } \\
\text { Energy-Efficient } \\
\text { Mortgages }^{40}\end{array}$ & $\begin{array}{l}\text { EEMs are available } \\
\text { only for first } \\
\text { mortgages on either } \\
\text { new construction that } \\
\text { meets exceeds MEC } \\
1995 \text { or existing } \\
\text { homes that can be } \\
\text { modified to meet MEC } \\
1995 .\end{array}$ & $\begin{array}{l}\text { Plan review by the } \\
\text { Energy Office for } \\
\text { Compliance, on- } \\
\text { site inspections by } \\
\text { the lender to verify } \\
\text { installation of } \\
\text { required energy } \\
\text { efficiency } \\
\text { construction } \\
\text { features, with a } \\
\text { home energy rating } \\
\text { optional at } \\
\text { completion; or in } \\
\text { the case of existing } \\
\text { homes, pre- } \\
\text { improvement } \\
\text { energy evaluation } \\
\text { and plan review, } \\
\text { and post- } \\
\text { improvement } \\
\text { inspection. }\end{array}$ & $\begin{array}{l}\text { EEMs up to a maximum of } \$ 250,000 \text { are } \\
\text { available for first mortgages that meet the } \\
\text { criteria (see left). EEMs for purchase of } \\
\text { existing homes are eligible for a } 1 / 4 \% \\
\text { reduction in interest rate; new } \\
\text { construction EEMs may qualify for } \\
\text { interest rate reductions of } 1 / 4 \%, 1 / 2 \% \text {, or } \\
1 \% \text { depending on construction details. } \\
\text { Eligible properties must be located within } \\
\text { Nebraska and the borrower must be a } \\
\text { Nebraska resident. }\end{array}$ \\
\hline
\end{tabular}

\footnotetext{
${ }^{37}$ Conversation with Ken Eklund, Idaho Department of Water Resources, Energy Division, June 16, 1999.

${ }^{38}$ Idaho's GEMSTAR program is in the final stages of developing an EEM program for site-built homes.

${ }^{39}$ Correspondence with Wade Byrd, Louisiana Department of Natural Resources, Energy Division, August 17, 1999.

${ }^{40}$ Conversations with Jack Osterman, Nebraska Energy Office, April 2, 1999, February 3, 2000 and February 18, 2000. Fax from Jack Osterman, February 18, 2000. "Nebraska Energy Efficient Mortgages" (1999) and "Dollar and Energy Savings Loans at 5\% Interest or Less for Home, Building, and System Improvements and More" (1997).
} 
Table 4. State EEM and Loan Programs (continued)

\begin{tabular}{|c|c|c|c|}
\hline State/Program & $\begin{array}{c}\text { Energy-Efficiency } \\
\text { Criteria }\end{array}$ & $\begin{array}{c}\text { Energy-Efficiency } \\
\text { Verification }\end{array}$ & Terms \& Conditions \\
\hline $\begin{array}{l}\text { Nebraska/ Dollar and } \\
\text { Energy Saving Loans }\end{array}$ & $\begin{array}{l}\text { Dollar and Energy } \\
\text { Saving Loans are } \\
\text { available for any of } \\
\text { a list of prequalified } \\
\text { improvements to } \\
\text { existing homes (i.e., } \\
\text { energy efficiency is } \\
\text { determined by } \\
\text { prescription) or } \\
\text { improvements } \\
\text { supported by an } \\
\text { energy audit and } \\
\text { meeting specific } \\
\text { simple payback } \\
\text { requirements. }\end{array}$ & $\begin{array}{l}\text { Under the loan } \\
\text { program, } \\
\text { improvements are } \\
\text { verified by preapproval } \\
\text { of quotes for each } \\
\text { type of project or } \\
\text { acceptance of the } \\
\text { energy audit by the } \\
\text { Energy Office and by } \\
\text { the requirement that } \\
\text { all work must be } \\
\text { completed within } 120 \\
\text { days of Energy Office } \\
\text { approval. Lenders } \\
\text { verify work completed. }\end{array}$ & $\begin{array}{l}\text { Under the loan program the total } \\
\text { amount that can be borrowed is } \\
\text { limited according to the type of project: } \\
\text { Residential project limits are } \$ 25,000 \\
\text { for single family and } \$ 75,000 \text { for multi- } \\
\text { family. The program brochure also } \\
\text { describes limits for Energy \& Dollar } \\
\text { Savings Loans to small and large } \\
\text { businesses and non-profits, farms and } \\
\text { ranches, local government divisions, } \\
\text { nursing homes, telecommunications } \\
\text { projects, alternate fuel projects, and } \\
\text { waste minimization projects. Loans } \\
\text { are offered at } 5 \% \text { annual percentage } \\
\text { rate or less, and can only be made for } \\
\text { the costs of goods and services, not } \\
\text { for the borrower's labor costs. Some } \\
\text { fees may apply (including origination } \\
\text { fees of up to } 2 \% \text { ), particularly if the } \\
\text { term of the loan is for the maximum } \\
\text { amount of time, which varies } \\
\text { according to type of project. Eligible } \\
\text { properties must be located within } \\
\text { Nebraska and the borrower must be a } \\
\text { Nebraska resident. }\end{array}$ \\
\hline $\begin{array}{l}\text { Tennessee Valley } \\
\text { Authority / energy right } \\
\text { Program }^{\circledR 2}\end{array}$ & $\begin{array}{l}\text { energy right } \\
\text { requires four stars } \\
\text { or a rating of } 80 \text { to } \\
82 \text { (equivalent to } \\
\text { MEC 92). } \\
\text { Energy right Gold } \\
\text { requires four and a } \\
\text { half to five stars or a } \\
\text { rating of } 83 \text { or better } \\
\text { (15\% or more better } \\
\text { than MEC 92). }\end{array}$ & $\begin{array}{l}\text { Can be either a } \\
\text { prescriptive- or } \\
\text { performance-based } \\
\text { verification method. } \\
\text { However, all program- } \\
\text { certified homes are } \\
\text { physically inspected } \\
\text { by a TVA professional, } \\
\text { in some instances } \\
\text { using software for a } \\
\text { performance-based } \\
\text { verification. }\end{array}$ & $\begin{array}{l}\text { The two levels of program certification } \\
\text { help home builders qualify for a range } \\
\text { of incentives. Buyers may qualify for } \\
\text { one or more of the following: }{ }^{43} \\
\text { - } \quad \text { Special financing including } \\
\text { reduced closing costs and interest } \\
\text { rates, } \\
\text { - } \quad \text { Reduced fees for application, } \\
\text { approval, affordability estimates, } \\
\text { - Enhanced client benefits and/or } \\
\text { gift packages, } \\
\text { - Free or low-cost package of } \\
\text { services, } \\
\text { Rate-lock-in option, } \\
\text { - } \text { Move-in services or discounts, } \\
\text { Qualification for higher-priced } \\
\text { home. }\end{array}$ \\
\hline
\end{tabular}

\footnotetext{
${ }^{41}$ Conversations with Jack Osterman, Nebraska Energy Office, April 2, 1999, February 3, 2000 and February 18, 2000. Fax from Jack Osterman, February 18, 2000. "Nebraska Energy Efficient Mortgages" (1999) and "Dollar and Energy Savings Loans at 5\% Interest or Less for Home, Building, and System Improvements and More" (1997).

${ }^{42}$ Conversation with Jerry Lyle, TVA, September 17, 1999.

${ }^{43}$ Under the TVA energy right ${ }^{\mathbb{B}}$ Residential New Homes Program there are tiered incentive levels: energy right and energy right Gold. Participating builders and participating lenders may selectively adopt different program options. EEM incentives offered through the energy right Program EEMs may differ from one participating building to another, or from one participating lender to another. E-mail from Jerry Lyle, November 4, 1999.
} 
Table 4. State EEM and Loan Programs (continued)

\begin{tabular}{|c|c|c|c|}
\hline State/Program Name & $\begin{array}{c}\text { Energy-Efficiency } \\
\text { Criteria }\end{array}$ & $\begin{array}{c}\text { Energy-Efficiency } \\
\text { Verification }\end{array}$ & Terms \& Conditions \\
\hline $\begin{array}{l}\text { Vermont / } \\
\text { Energy Improvement } \\
\text { Mortgage Service } \\
(\text { EIMS) }\end{array}$ & $\begin{array}{l}\text { Improvement } \\
\text { package must be } \\
\text { "cost effective," } \\
\text { annual savings } \\
\text { greater than } \\
\text { mortgaged cost. }\end{array}$ & Rating & $\begin{array}{l}\text { Turn-key services to home buyers to } \\
\text { incorporate energy improvements into } \\
\text { their mortgage. ERH-VT rates the } \\
\text { home, writes up work specifications, } \\
\text { puts them out for bid, assembles the } \\
\text { rating package with firm, fixed bids, } \\
\text { coordinates with the lender for } \\
\text { financing (available through Freddie } \\
\text { Mac, Fannie Mae, FHA, VA or } \\
\text { Vermont Housing Finance Agency), } \\
\text { implements contracts with chosen } \\
\text { contractors, oversees the work, } \\
\text { performs final inspection and re-rates } \\
\text { the house. ERH-VT charges } \$ 800+ \\
\text { for this service, which can be financed } \\
\text { under some programs. }\end{array}$ \\
\hline $\begin{array}{l}\text { Vermont / } \\
\text { Vermont Housing } \\
\text { Finance Agency's } \\
\text { Yearly Energy Savings } \\
\text { System (YESS) } \\
\text { Program }\end{array}$ & $\begin{array}{l}\text { At least } \$ 2,500 \text { of } \\
\text { "cost effective" } \\
\text { improvements rolled } \\
\text { into mortgage. }\end{array}$ & Rating & $\begin{array}{l}\text { Stepped interest rate incentive for } \\
\text { participants. As of January, } 2000 \text {, } \\
\text { rates for 1-point mortgage are: } \\
\text { Year 1: } 5.45 \% \\
\text { Year 2: } 5.95 \% \\
\text { Year 3: } 6.45 \% \\
\text { Years } 4-30: 6.95 \% \text { fixed } \\
\text { EIMS (see above) utilized for every } \\
\text { customer. }\end{array}$ \\
\hline $\begin{array}{l}\text { Vermont / } \\
\text { Vermont Energy } \\
\text { Investment Corporation } \\
\text { (VEIC) ENERGY STAR } \\
\text { Loan }{ }^{46}\end{array}$ & $\begin{array}{l}\text { Any “ENERGY } \\
\text { STAR" certified } \\
\text { products (plus } \\
\text { renewables). }\end{array}$ & $\begin{array}{l}\text { Copy of contractors' } \\
\text { invoice, customers' } \\
\text { signed approval of } \\
\text { installation. }\end{array}$ & $\begin{array}{l}\text { Unsecured consumer loan up to } \\
\$ 20,000 \text { with terms of } 3,5,7 \text { or } 10 \\
\text { years and interest rates generally } \\
\text { between } 11 \% \text { and } 15 \% \text {, depending on } \\
\text { the loan amount. } 24 \text { hour approval, } \\
\text { no points, no fees. }\end{array}$ \\
\hline
\end{tabular}

\section{Federal Agency Activity}

\section{DOE Five-Year Pilot of HERS Provider Organizations ${ }^{47}$}

To increase the market penetration of HERS and EEMs, DOE supplied funding to a total of seven states during a five-year pilot program. In 1994, five HERS providers in Alaska, Arkansas, California, Vermont, and Virginia were funded to recruit and train raters, process ratings, and provide assistance to other states that wanted to start HERS programs. In 1995, Colorado was added to the pilot program, and in 1996 Mississippi was added to the pilot program. The number of ratings completed in the pilot states is shown in Table 5, and the number of HUD-Federal Housing Authority (FHA) EEMs is shown in Figure 2 .

Although each of the pilot states' circumstances are different, there are some common themes. Over the course of the pilot program, HERS providers who exhibited some of the following factors had a higher market penetration of home energy ratings, and higher EEMs or other financing that used a HERS.

\footnotetext{
${ }^{44}$ E-mail from Richard Faesy, Energy Rated Homes of Vermont, January 4, 2000.

${ }^{45}$ E-mail from Richard Faesy, January 4, 2000.

${ }^{46}$ E-mail from Richard Faesy, January 4, 2000.

${ }^{47}$ Farhar, B.C. HERS/EEMs Pilot States Program Report. (2000)
} 
Table 5. Ratings Completed in Pilot States (By Calendar Year)

\begin{tabular}{|l|c|c|c|c|c|c|}
\hline \multicolumn{1}{|c|}{ State } & $\mathbf{1 9 9 4}$ & $\mathbf{1 9 9 5}$ & $\mathbf{1 9 9 6}$ & $\mathbf{1 9 9 7}$ & $\mathbf{1 9 9 8}$ & Total 1994 - 1998 \\
\hline Alaska & 3,293 & 2,869 & 628 & 577 & 515 & 7,882 \\
\hline AHFC $^{\mathrm{A}}$ & -- & -- & 416 & 1021 & 2092 & 3,529 \\
\hline Arkansas $^{\mathrm{B}}$ & 98 & 119 & 98 & 87 & 69 & 471 \\
\hline California $^{\mathrm{C}}$ & 8,378 & 548 & 1,302 & 2,374 & 4,674 & 17,276 \\
\hline Colorado $^{\mathrm{D}}$ & -- & 185 & 529 & 1,284 & 1,814 & 3,812 \\
\hline Mississippi & -- & -- & 32 & 21 & 19 & 72 \\
\hline Vermont & 363 & 427 & 523 & 381 & 354 & 18,370 \\
\hline Virginia & 250 & 7,345 & 4,275 & 3,000 & 3,500 & 53,460 \\
\hline Totals & 12,382 & 11,493 & 7,803 & 8,745 & 13,037 & \\
\hline
\end{tabular}

Source: Data provided by the DOE pilot states HERS provider organizations and the AHFC.

A Alaska Housing Finance Corporation started performing ratings in 1996 without DOE pilot funds

B Arkansas HERS provider began doing ratings in Missouri in 1996 - performed 126 in 1996, 129 in 1997 and 114 in 1998.

$\mathrm{C}_{\text {Includes all but one HERS provider in California. }}$

D Colorado did not begin ratings until 1995.

E Data for 1996 - 1998 was converted from fiscal year to calendar year format. Actual fiscal year data: 1/96-6/96 277; 7/96-7/97 492; 7/97-6/98 270; 7/98-12/98 219.

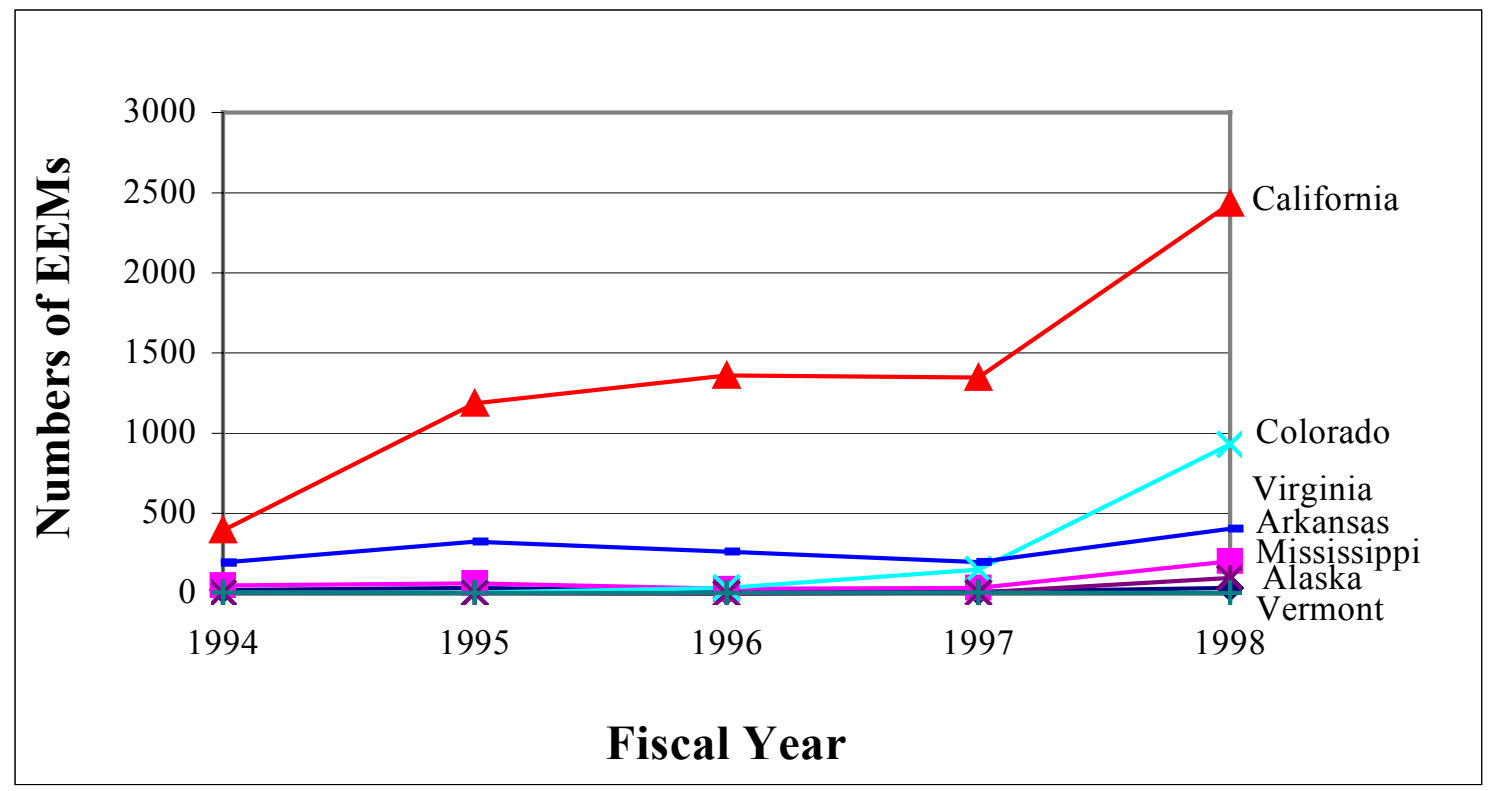

Figure 2. HUD-FHA EEMs in DOE Pilot States ${ }^{48}$

HERS programs in Alaska, California and Colorado each received relatively high levels of funding during short periods of time, which may have resulted in increased HERS activities for those states. The HERS program in Alaska received $\$ 825,000$ for FY 1994 - FY 1995; the HERS program in California received \$3.2 million for FY 1994 - FY 1995; and the HERS program in Colorado received \$2.5 million for FY 1997 - FY 1998.

\footnotetext{
${ }^{48}$ Data provided by Maurice Gulledge, Data Warehouse Manager, HUD-FHA, Single Family Loan Housing, March 24, 1999.
} 
Financial incentive for energy-efficient financing (mortgages or loans) for mortgage borrowers. Offering a slight interest rate break for EEMs (on the order of a quarter-point mortgage interest rate reduction) would make these mortgages more attractive to borrowers (although the incentive to lenders of offering an interest rate break is unclear). Although not officially connected with the DOE pilot program, the Alaska Housing Finance Corporation (AHFC) offers such an interest rate break to borrowers for existing homes and new construction. In 1998, 1,151 AHFC loans were completed. ${ }^{49}$ (In contrast, only 32 HUD FHA EEMs were completed in Alaska in 1998.) The Yearly Energy Savings System (YESS) ${ }^{50}$ program in Vermont is an energy-improvement mortgage program that offers an interest rate reduction to energy-efficient mortgage borrowers for existing homes. The Energy Rated Homes Loan Program, offered in Alaska, offers unsecured loans for existing houses of $\$ 1,000-\$ 20,000$ for qualifying energyefficient home improvements with no loan application fee. ${ }^{51}$

Financial incentive for lenders to market EEMs. In 1998, Virginia offered a \$2,000 recognition award for the lender completing the highest number of EEMs in Virginia. A relatively high number of EEMs, 375, were completed in Virginia using ratings from the Virginia Home Energy Rating Organization (HERO) program. This observation suggests that aggressive marketing of EEMs by the mortgage community may be important to increasing the number of EEMs achieved, and that a financial incentive for lenders could increase lender marketing efforts.

Diversification of services. Vermont's HERS program has been incorporated into a larger entity (a nonprofit organization), and offers a suite of services including, besides home energy ratings, a turn-key service for lenders, code compliance documentation, and appraiser training. The Virginia HERS program offers several services including consulting on inner-city housing affordability, development of innovative energy-efficient financing products, and financial incentives for lenders. Mississippi's program also offers several services including "EnergyCheck," a checklist of viable energy-efficiency options for the homeowner. Organizations that combine their home energy rating services with other energy-efficiency, housing, and mortgage lending services may increase the probably of their viability without federal funding. Packaging services appears to have three aspects: (1) diversification of services to add value that the market recognizes and is willing to pay for; (2) sharing of administrative costs so that the incremental cost of each rating processed is reduced; and (3) reducing per-unit rating cost through working with large production builders.

Continuity in HERS program leadership. Continuity in program leadership, combined with experienced HERS program leaders, appears to be another key factor in likelihood of sustained operation. Alaska, Vermont, and Virginia have had the same directors for the duration of the five-year pilot program, which appears to have strengthened each of these programs. The other pilot states have experienced major shifts in leadership, which could have cost them some momentum.

Active stakeholder involvement and relative size of state population. The extent of stakeholder involvement appears to be another factor. The two least-populated states, Alaska and Vermont, appear to have completed, proportionally, the most ratings. This may be, at least in part, a function of a smaller state's greater opportunities for interaction among the prominent stakeholders in the energy, building, housing finance, lending, real estate, appraisal, government, and rating-provider communities. The active participation of key stakeholders appears to enhance a program's effectiveness in completing ratings.

\footnotetext{
${ }^{49}$ Alaska Housing Finance Corporation Energy Efficiency Interest Rate Reduction Program (EEIRR). http://www.ahfc.state.ak.us/Department_Files/Energy/Energy_Main_Page.htm. Date accessed, November 11, 1999.

${ }^{50}$ The Yearly Energy Savings System (YESS) Mortgage program for existing homes allows borrowers eligible for financing from the Vermont Housing Finance Authority to make their homes more energy efficient with a reduced interest rate starting at 5.45\%. YESS finances up to $100 \%$ of the cost of approved energy improvement. http://www.erhvt.org/yess7-99htm. Date accessed, November 11, 1999.

${ }^{51} \mathrm{http}: / /$ www.erha.com/alaska/loan.htm. Date accessed, November 11, 1999.
} 
Beyond providing HERS in their own states, Alaska, Arkansas, Colorado, Mississippi, and Vermont have taken a regional approach. By offering ratings in other states the amount of rating activity actually performed by the pilot state is underreported by only examining the ratings numbers in the pilot state. These pilot states plan to use the existing infrastructure developed for the pilot program and expand HERS coverage to other surrounding states (or in Alaska's case, expanding to the southwestern part of the United States). Vermont and Alaska are offering a loan program for energy-efficiency improvements for existing homes in an attempt to increase the amount of improvements to existing homes. Mississippi and Vermont are offering other related services for fees including energy audits on small commercial buildings, simpler residential audits, and other residential energy services. Colorado is seeking to license their software system for managing rater certification information and ratings.

Many of the HERS provider organizations in the pilot states believe that additional federal funding is needed for their organizations, as well as funding for national marketing and public service announcements. All of the HERS provider organizations believe that programs like ENERGY STAR Homes should be required to use ratings for their certifications. Currently, the cost of delivering ratings is higher than the fees charged for ratings, resulting in a net loss for each rating performed.

\section{DOE State Energy Program HERS Grants}

As a result of specific Congressional appropriations language, HERS funds were set aside for non-pilot states to assist in developing programs in FY98 and FY99 via a competitively selected process. In addition to funding HERS pilot programs in seven states (Alaska, Arkansas, California, Colorado, Mississippi, Vermont, and Virginia), DOE also awarded State Energy Program (SEP) special projects grants to promote HERS in 11 other states. ${ }^{52}$ In FY98, DOE awarded grants to Delaware, Idaho, Kentucky, Michigan, Nebraska, Washington, and Wisconsin. In FY99, DOE awarded additional SEP special project grants to Florida, Idaho, Iowa, Kansas, Ohio, and Wisconsin. [In addition to these states, SEP-funded HERS activities have been reported by the State Energy Offices (SEOs) in Illinois and Utah. $\left.{ }^{53}\right]$ The HERS SEP grantee states report a range of progress, stretching from "little progress" to "the beginnings of market penetration."

As of spring 1999, of the above-mentioned states funded in FY98 and FY99, Idaho, Iowa, Kansas, Nebraska, Washington, and Wisconsin reported that they have active HERS programs in place for training and certifying raters and providing ratings. Kentucky and Ohio report that they do not have HERS programs in place but are developing HERS programs by negotiating reciprocity agreements ${ }^{54}$ with other states' HERS providers. In addition, other states are using regional cooperative efforts to provide ratings in their states, such as in the Northeast and the Northwest. ${ }^{55}$

Interviews also revealed that the majority of the states receiving SEP grants plan to engage in activities to either strengthen or widen the reach of programs that are already successful. An example of this is the state of Florida, where the state energy office, two university-related entities (a research center and an extension service), the ENERGY STAR Homes program, and builders, lenders, and real estate professionals have developed an independent HERS/EEMs program. Florida intends to use FY99 special

\footnotetext{
${ }^{52}$ The 11 states are Delaware, Florida, Idaho, Iowa, Kansas, Kentucky, Michigan, Nebraska, Ohio, Washington, and Wisconsin.

${ }^{53}$ Phone interviews with SEO officials, April - August, 1999.

${ }^{54}$ Reciprocity agreements allow one state's ratings provider to provide ratings in another state.

${ }^{55}$ Organizational agreements refer to the formal alliance with regional or national organizations such as Energy Rated Homes of America and National HERO. In the Northeastern states of Connecticut, Maine, Massachusetts, New Hampshire, New York, Rhode Island, and Vermont, state energy officials are collaborating on HERS-EEMs through two organizations: the Northeast Energy Efficiency Partnerships, Inc. (NEEP), which provides support to state energy code activities, and performs some work with HERS; and the Northeast Home Energy Rating System Alliance (NE HERS Alliance), which stimulates demand for the creation of energy-efficient, comfortable and affordable housing. NE HERS Alliance works to standardize HERS, EEMs and ENERGY STAR Homes in the housing markets throughout the northeast region. In the Northwest, Washington state energy office reports that they are cooperating with both Idaho and Oregon to develop HERS.
} 
project funding to further strengthen the training and outreach efforts in those areas of the state with the most activity. The stakeholders believe that by focusing their efforts in an already active area, the program will naturally spread to other building markets, such as small commercial buildings.

\section{U.S. Department of Housing and Urban Development Federal Housing Administration Energy-Efficient Mortgages}

HUD-FHA's main activity is to insure residential mortgage loans made by private lenders. Although HUD-FHA neither buys nor originates mortgages, it sets standards for mortgage underwriting through its insurance function. HUD-FHA insured loans are open to all qualified buyers of moderately priced homes (up to a maximum loan value of $\$ 219,849$ for a one-family house as of $1 / 1 / 00^{56}$ ). In 1998, HUD-FHA's total mortgage loan business (not including their loan insurance business) represents between $12 \%$ and $15 \%$ of the total U.S. market for mortgage loan originations. ${ }^{57}$

HUD-FHA has promoted energy efficiency in housing since the early 1970s. In response to EPACT, in May 1993, HUD established the EEM pilot $\operatorname{program}^{58}$ for existing properties in five states: Alaska, Arkansas, California, Virginia, and Vermont. ${ }^{59}$ In August 1993, HUD required that new residential structures (single-to-four-family dwellings) meet or exceed MEC 1992 to be eligible for HUD insured mortgage financing. ${ }^{60}$ During the period from 1994 through 1999, the number of HUD-FHA EEMs has, on average, more than doubled every year.

In 1995, the HUD-FHA EEM was extended nationwide for construction of new homes as well as retrofits to existing homes. ${ }^{61}$ The same mortgagee letter made two other significant changes: it allowed EEMs to be written as adjustable rate mortgages, and made renovations ${ }^{62}$ eligible for EEMs under Section 203(k) of the Housing and Community Development Act of 1992. If a rating is used to determine the cost effectiveness of a renovation, the EEM can be applied to renovate a dwelling as large as a four-family dwelling.

As of 1997, the HUD-FHA EEM can be used in conjunction with Section 203(h), mortgages made to replace or rebuild homes destroyed in disasters. ${ }^{63}$ Section 203(h) of the Housing and Community Development Act of 1992 authorized HUD to offer special underwriting to victims of events declared disasters by the President as relief to their efforts to rebuild, repair, or renovate homes damaged or destroyed by the disaster.

For all EEMs except the 203(h) (i.e., new construction, renovation, and improvements to existing homes), the energy-efficient features must surpass those required for compliance with the current FHA energy conservation standards for new construction the Council of American Building Officials (CABO) 1992 Model Energy Code (MEC). ${ }^{64}$

\footnotetext{
${ }^{56}$ The current basic standard mortgage limit for FHA insured loans is $\$ 121,296$ for a one-family house. However, in high-cost areas the limits are subject to a ceiling based on a percentage of the Freddie Mac Loan limits. The ceiling for a one-family house in a high-cost area is $\$ 219,849$. From the HUD-FHA web site: www.hud.gov/fha/sfh/fhasfhbus.html. Date accessed: January 30, 2000. Date last modified: January $29,2000$.

${ }^{57}$ Based on calculations by the author using data from the HUD-FHA Single-Family Loan Office and the Mortgage Bankers Association web site, url: http://www.mbaa.org/marketdata/. Date accessed: December 10, 1999.

${ }^{58}$ The Housing and Community Development Act (Section 513) (Public Law 102-550) and EPACT (Section 106) provided authority for HUD to undertake these EEMs activities.

${ }^{59}$ Mortgagee Letter 93-13, url: http://www.hudclips.org. Date accessed: December 14, 1999.

${ }^{60}$ Mortgagee Letter 93-26, from the Office of the Assistant Secretary for Housing-Federal Housing Commissioner, dated August 24, 1993. This policy was to become effective October 24, 1993, but was modified by an extension in order to avoid disruption of home building and selling in process during the implementation period. The extension was announced by Mortgagee Letter 93-35, dated October 24, 1993.

${ }_{61}^{61}$ Mortgagee Letter 95-46, url: http://www.hudclips.org. Date accessed: December 14, 1999.

${ }^{62}$ Renovations are residential construction projects that substantially improve an existing dwelling so that it may be made habitable.

${ }^{63}$ Mortgagee Letter 97-10, url: http://www.hudclips.org. Date accessed: December 14, 1999.

${ }^{64}$ As of November 1999, HUD-FHA had begun consideration of adoption of the 1995 MEC, "Assessment of the 1995 Model Energy Code for Adoption," http://www.huduser.org/publications/destech/mec.html. Date accessed: December 10, 1999.
} 
In all cases, the HUD-FHA EEM program requires that the improvements be deemed cost effectivemeaning that the present value of the energy saved over the life of the energy-efficiency investment must exceed the cost of the energy-efficient improvements. The FHA program does not require an appraisal of the energy improvements or further scrutiny of the borrower's credit qualifications.

For new construction, HUD-FHA always requires that a rating validate the energy and cost savings required by an EEM. However, data indicate that, in some states, the number of EEMs reported may be inaccurate. In Arkansas and Mississippi, best-available data show that more EEMs are being reported than there are ratings being completed. Several factors could affect these counts. Well-known EEM reporting problems in the Computerized Homes Underwriting Management System (CHUMS) data system include: loan officers may be failing to record actual EEMs or loan officers may be designating loans as EEMs that are not actually EEMs when loan data are entered into the CHUMS system; and data are reported in two ways - calendar year, a 12-month period from January through December, and fiscal year, a 12month period from July through June- because they are reported in two ways they are difficult to accurately compare. ${ }^{65}$

- Regardless of the questionable data, the HUD-FHA numbers show a consistent growth pattern in the use of EEMs between 1994 and 1999, as seen in Figure 3.

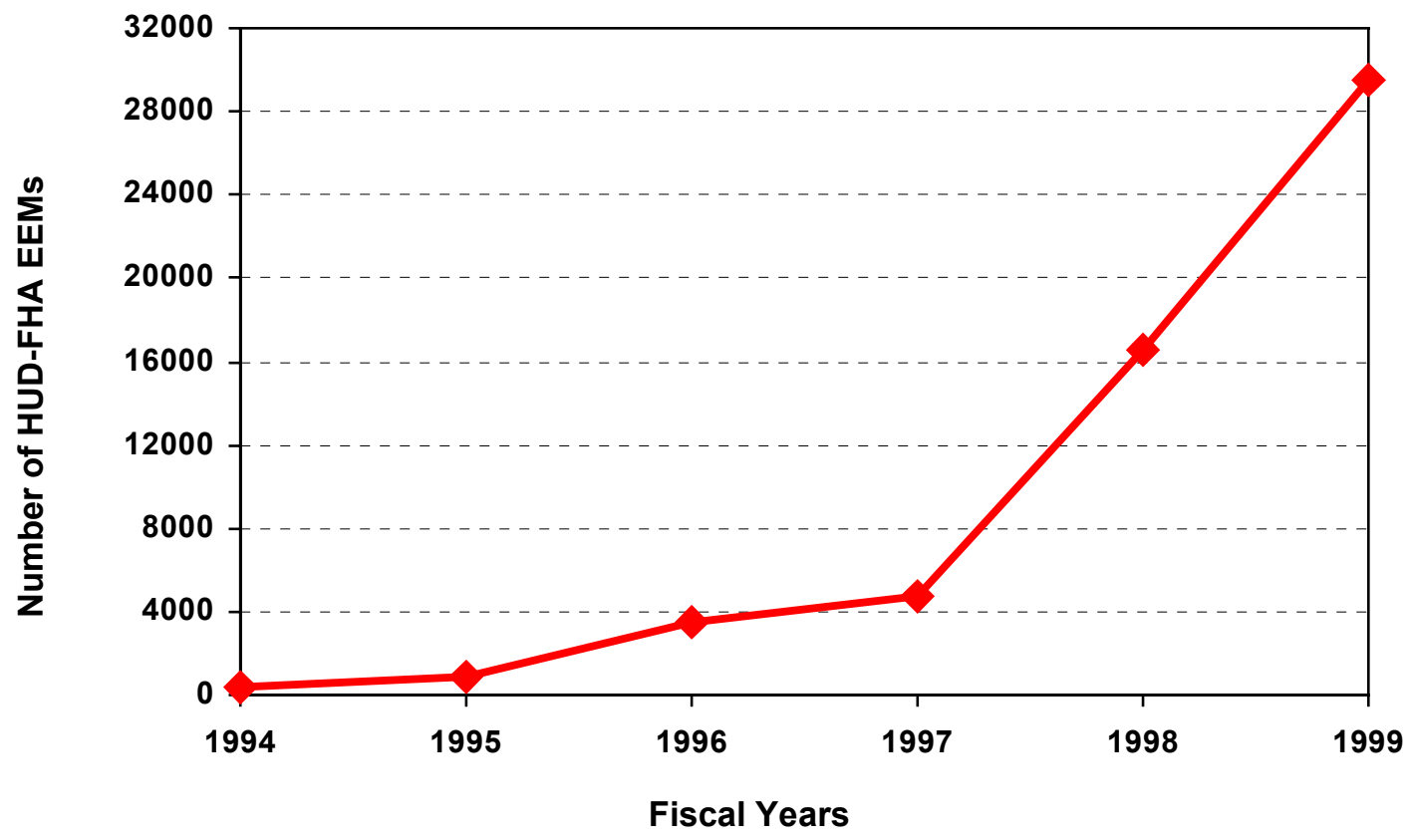

Figure 3. HUD-FHA EEMs Fiscal Years 1994-199966

\section{Department of Veterans Affairs Energy-Efficient Mortgages}

The Department of Veterans Affairs (VA) offers EEMs to qualified military personnel, reservists, and veterans in all 50 states for energy-efficiency improvements to existing homes at the time of purchase. Up to $\$ 3,000$ of improvements can be financed based solely on documented costs. Upgrades up to $\$ 6,000$

\footnotetext{
${ }^{65}$ Farhar, Collins, and Walsh (1997), pp. 47-48.

${ }^{66}$ For FY94 - FY98, data provided by Maurice Gulledge, Data Warehouse Manager, HUD-FHA, Single Family Loan Housing, March 24, 1999, for FY99, data provided by Robert Groberg, Director, Energy Division, HUD, January 28, 2000.
} 
are possible if deemed cost effective. The numbers of EEMs generated by the VA program has not exceeded 1,000 in any of the six years of the program, and cumulatively represent less than $4,300 .{ }^{67}$

\section{United States Department of Agriculture Rural Housing Service Guaranteed and Direct Loans}

U. S. Department of Agriculture Rural Housing Service (USDA-RHS) offers loans for home purchases and renovations that require modest energy-efficiency features (e.g., a specified level of insulation). The direct loan program provides $100 \%$ financing directly to qualified low-income rural homebuyers. The guarantee program is RHS's involvement in the secondary mortgage market. Although these RHS loans are not the same as EEMs, data were collected and analyzed in this report for both types of RHS loan. Overall, RHS loans do not represent a large share of the market. In FY94 (the year with the greatest number of RHS loans for the period 1994 to 1998), 31,200 RHS loans were made, ${ }^{68}$ which represents less than half the number of FHA new home loans for the same year $(89,700){ }^{69}$

\section{U.S. Environmental Protection Agency ENERGY STAR Homes}

As a component of the DOE/EPA Energy Star Program, the ENERGY STAR Homes program—managed by EPA - began in 1995. The program helps builders to promote construction of homes that are $30 \%$ more efficient than MEC. The program distinguishes energy-efficient homes with a brand name label certification system and a preferred mortgage financing network. According to EPA, as of July 1999, ENERGY STAR Homes certified over 9,000 homes, recruited over 1,000 builder partners, and has over 250 rating providers and home energy raters as ENERGY STAR Homes Allies. ${ }^{70}$ The number of homes certified as ENERGY STAR Homes is shown in Table 6.

Table 6. Number of Homes Nationwide Certified as ENERGY STAR Homes

\begin{tabular}{|l|c|c|c|c|c|}
\hline \multicolumn{1}{|c|}{ Year } & $\begin{array}{c}\text { HERS } \\
\text { Ratings }\end{array}$ & $\begin{array}{c}\text { Sampled } \\
\text { Ratings }\end{array}$ & $\begin{array}{c}\text { Builder Option } \\
\text { Packages }\end{array}$ & $\begin{array}{c}\text { Sampled } \\
\text { Builder Option } \\
\text { Packages }\end{array}$ & $\begin{array}{c}\text { Total Certifications } \\
\text { Per Year }\end{array}$ \\
\hline 1995 & 2 & 0 & 0 & 0 & 2 \\
\hline 1996 & 194 & 0 & 0 & 0 & 0 \\
\hline 1997 & 1045 & 553 & 0 & 0 & 194 \\
\hline 1998 & 3720 & 285 & 1049 & 5 & 5054 \\
\hline $1999^{*}$ & 1741 & 350 & 205 & & 2301 \\
\hline $\begin{array}{l}\text { Total } \\
\text { Since } \\
\text { Start }\end{array}$ & 6702 & 1188 & 1254 & 5 & $\mathbf{9 1 4 9}$ \\
\hline
\end{tabular}

${ }^{*}$ Through July 1999

The ENERGY STAR Mortgage program is a promotional effort designed to encourage mortgage lenders to use EEMs for certified ENERGY STAR Homes. An ENERGY STAR mortgage offers a minimum 2\% stretch on an applicant's maximum debt-to-income ratio, plus at least one additional feature designed to encourage borrowers to purchase ENERGY STAR Homes. Two national lenders, Chase and Countrywide, currently provide ENERGY STAR Mortgages. At the state level, 10 other lenders are promoting EEMs for purchases of new homes with the ENERGY STAR certification. Countrywide's and Chase's national mortgage products resemble the standard $2 \%$ stretch ratio products, but with added incentives such as discounts on closing, special underwriting allowances, and fee waivers. Some lenders may offer interest rate discounts, paying for the cost of the rating and/or extending special debt-to-income

\footnotetext{
${ }^{67}$ Conversation with Kathleen Mangold, Loan Guarantee Service, Department of Veterans Affairs, March 12. 1999.

${ }^{68}$ Conversation with Dean Daetwyler, Senior Loan Specialist, Guaranteed Loan Division of USDA Rural Housing Services, March $19,1999$.

${ }^{69}$ Based on calculations by the author using data from the USDA Rural Housing Service and the HUD-FHA Single Family Loan Office.

${ }^{70}$ From the EPA web site: http://yosemite.epa.gov/appd/eshomes/eshomes.nsf. Date accessed: July 26, 1999.
} 
ratios—as high as 4\%. ${ }^{71}$ EPA's dedication to working with lenders bodes well for EEMs, and potentially for HERS.

In the first three years of the ENERGY STAR Homes program, EPA required that its ENERGY STAR Homes label be used only on new homes that have been rated as 86 or higher on the home energy rating scale, which corresponds to 30\% more efficient than the MEC 1992. Builders expressed concern about the complexity and cost of providing ratings for each new home as well as adding another third-party inspection to the process of building a home. In response to these concerns, EPA has developed alternative certification methods which could reduce the "per house" cost of certification. One alternative, a builder option package (BOP $)^{72}$, comprises an approved checklist of energy improvements that builders can implement to obtain ENERGY STAR certification. The prescribed improvements are designed to bring a home's energy efficiency to an 86 level. EPA designed the ENERGY STAR Homes program to be flexible and has worked with builders at the beginning of the program on a case-by-case basis to meet the ENERGY STAR energy-efficiency criteria. EPA designed the BOPs with the assistance of ENERGY STAR Allies. ${ }^{73}$ To achieve the ENERGY STAR Homes label, some builders chose to have all their homes rated, some builders chose to have their homes rated using a sampling protocol, and some builders chose to have their homes inspected by a third party to verify the measures of the BOP using a similar sampling protocol.

With the aforementioned sampling protocol, ENERGY STAR Homes requires that the first three homes constructed by a builder either be (a) rated using a HERS or (b) inspected by a third-party to ensure that the prescriptive measures in the BOP have been incorporated by the builder. Once the first three homes have either been rated or inspected and meet the energy-efficiency criteria of ENERGY STAR Homes, then $15 \%$ of the rest of the homes would be randomly selected to either be rated or inspected in the same manner as the initial three homes. In December of 1999, EPA is reviewing the sampling protocol for both HERS and BOP inspections and testing the homes that qualified as ENERGY STAR Homes using the sampling protocol to determine if the sampling protocol has been effective. Both sampling methods are less expensive than performing a rating on every house. However, HERS providers believe EPA should continue to require home energy ratings for each house labeled as an ENERGY STAR Home to ensure that the house meets efficiency standards as well as to ensure a market for their services. ${ }^{74}$

To address this situation, ENERGY STAR Homes program has responded by providing marketing materials to assist HERS providers in marketing ratings services to builders by showing that using a HERS rather than a builder option package can be less expensive. The marketing materials contain a cost comparison fact sheet that compares the two technical verification systems - custom HERS review versus builder option packages. This comparison "show[s] that a custom HERS review can offer a...net lower cost," with a difference of $\$ 870$ in favor of HERS. ${ }^{75}$

\section{Energy-Efficient Mortgage Activities}

This section summarizes the variety of non-federal energy-efficiency financing activities. Programs fall into two general categories, those operating in the secondary mortgage market and those operating in the primary mortgage market. Fannie Mae and Freddie Mac operate in the secondary mortgage market by

\footnotetext{
${ }^{71}$ From “Key Features of ENERGY STAR Mortgage Products as of 7/30/99," provided by EPA's ENERGY STAR Mortgage Program Director. ${ }^{72}$ BOP: An EPA approved set of specification and conditions determined to be equivalent or more stringent than the minimum requirements for an ENERGY STAR Home. BOPs are limited by geographic areas ranging from a single subdivision to large regional areas of the country. BOPs require the same field inspection and tests as a HERS rating, but produce a "pass/fail" result, rather than a "score." ENERGY STAR Homes BOP Providers Approval Procedures, draft September 24, 1999, provided by David Lee, EPA on December 6, 1999.

${ }_{73}^{73}$ From the EPA website: http://yosemite.epa.gov/appd/eshomes/eshomes.nsf. Date accessed: December 10, 1999.

${ }^{74}$ Builder Caught in Crossfire over Energy Star Test Protocols," Energy Design Update, Vol., 19, No. 7, July 1999.

${ }^{75}$ Draft factsheet, "ENERGY STAR Technical Verification: Home Energy Ratings System (HERS) Ratings vs. Builder Option Packages (BOP),

Based on Sample Home in Columbus, Ohio.” Provided by David Lee, EPA’s ENERGY STAR Program Director. December 10, 1999.
} 
purchasing loans from primary lenders allowing them to then make additional new loans. Fannie Mae and Freddie Mac have established criteria that provide borrowers with certain incentives to purchase energy-efficient homes or to make homes more efficient. These criteria include increasing the amount of money that can be loaned by increasing a borrower's debt-to-income ratio. ${ }^{76}$ Primary lenders use Fannie Mae and Freddie Mac criteria and offer a variety of incentives including waiving certain fees and reducing closing costs.

\section{Secondary Mortgage Market, Government-Sponsored Enterprises}

\section{Federal National Mortgage Association}

In June 1999, the Federal National Mortgage Association (Fannie Mae) announced a new EEM that allows the use of several approved home energy ratings methods and prescriptive programs to evaluate energy efficiency and estimate the resulting cost savings. Both existing and new residential properties are eligible nationwide. This new Fannie Mae pilot does not require a HERS, but accepts a HERS as one method of verification, either as part of a prescriptive program via random sampling or on individual homes.

Under the terms and conditions of this EEM, the energy savings are translated into mortgage dollars, and the value that the savings adds to the house is recognized. The present value of the savings is added to the appraised value of the house to recognize the value added by the energy-efficiency features. ${ }^{77}$

Fannie Mae expects that more builders will participate in this EEM because: 1) the energy efficiency of a home can be certified by either a home energy rating or a prescriptive method; and 2) sampled ratings will be allowed for certifying new construction (which reduces builder costs by reducing the number of ratings required for a large development) ${ }^{78}$ Both scientific ratings and prescriptive programs are acceptable, including the ENERGY STAR Homes certification, Edison Electric Institute's (EEI's) E Seal certification, HERS ratings, and "other programs as approved by Fannie Mae.",79

If the borrower qualifies for a maximum monthly mortgage payment of $\$ 1,000$ and the energy savings is shown to be $\$ 50$ per month, then the lender may increase the borrower's maximum mortgage payment to $\$ 1,050$, limited only by the loan-to-value ratio. ${ }^{80}$

With this EEM, the cost of the improvements is limited to $15 \%$ of the total cost of the house for existing homes. ${ }^{81}$ Therefore on a $\$ 100,000$ house, up to $\$ 15,000$ of improvements could be made-providing the improvements are documented to be cost effective. There is no limit imposed on the cost of improvements for new construction. ${ }^{82}$

A homebuyer can finance $100 \%$ of the energy-efficiency improvements without a corresponding increase in down payment. For example, if a homebuyer selects a $\$ 100,000$ home and wants to add $\$ 10,000$ of cost-effective, energy-efficiency improvements and the lender requires a $20 \%$ down payment, the homebuyer's EEM would be for $\$ 110,000$ with a down payment of $\$ 20,000$. Therefore the total mortgage would cover the cost of the house and the energy-efficiency improvements. ${ }^{83}$

\footnotetext{
${ }^{76}$ However, increasing the debt-to-income ratio only serves as an incentive to a small percentage of borrowers, since the majority of borrowers do not apply for the maximum amount for which they qualify.

${ }^{77}$ Telephone conversation with Patricia O'Loughlin, Fannie Mae, November 8, 1999.

${ }^{78}$ Document from Patricia O'Loughlin, Fannie Mae, June 6, 1999.

${ }^{79}$ Telephone conversation, Patricia O'Loughlin, June 11, 1999.

${ }^{80}$ The loan-to-value limit is defined by the ratio of the value of the property divided by the total amount of the loan-including the value of the energy efficiency improvements. Fannie Mae's EEMs have always required that the final loan-to-value limit must not exceed $95 \%$.

${ }^{81}$ From document provided by Patricia O’Loughlin, Fannie Mae Home Improvement Loans Division, June 6, 1999; and from a Fannie Mae press release dated June 10, 1999.

${ }_{82}^{82}$ Telephone conversation with Patricia O'Loughlin, November 8, 1999.

${ }^{83} 100 \%$ financing of the energy improvements is allowed up to the limit of the loan-to-value ratio (95\%).
} 
Furthermore, in June 1999 Fannie Mae and the National Association of Home Builders (NAHB) announced a partnership that includes energy-efficient mortgages as one of many planned environmental initiatives. Fannie Mae's partnership with NAHB is intended to bring about positive environmental features beyond energy efficiency, such as the use of recycled content and ecologically innovative materials and supplies, proximity to public transportation, energy- and water-saving landscaping, etc. ${ }^{84}$

Prior to the release of this national initiative, Fannie Mae had been offering a pilot EEM in nine states. The terms and conditions of Fannie Mae's prior EEM pilot programs are similar to the HUD-FHA EEM, both of which are still being used in some states. These other programs, based on the $2 \%$ stretch in the debt to income ratios, have a lesser appeal since many mortgage lenders have the freedom to extend a larger stretch at their discretion, without energy-efficiency considerations. Currently, Fannie Mae does not have available information on the number of EEMs that are done by the lenders.

In addition to these EEMs, Fannie Mae reports that they have made more than 40,000 unsecured energy improvement loans between 1995 and 1998 for improvements to existing homes. ${ }^{85}$

\section{Federal Home Loan Mortgage Corporation}

The Federal Home Loan Mortgage Corporation's (Freddie Mac's) energy-efficient mortgage activities in the secondary mortgage market are limited to financing of purchases of existing-energy efficient residential properties or properties that are to be retrofitted or renovated for energy efficiency. Freddie Mac's EEM is similar to the $2 \%$ stretch ratios but can exceed the $2 \%$ stretch at the lender's discretion. The lender may extend higher ratios of "housing expense-to-income" and/or "monthly-debt-payment-toincome," if energy-efficiency savings are considered.

In general, Freddie Mac's EEM guidelines are intentionally less explicit than HUD-FHA or Fannie Mae, so that the lender can have the flexibility to "make a greater number of energy-efficient loans." In the case of the higher ratios, Freddie Mac maintains the strength of their EEM portfolio by requiring that source documentation be provided with the loan file. This documentation must show "the dollar offset allowed due to lower utility charges," and must be one of the following: A) HERS rating report; B) Form $70 \mathrm{~A}^{87}$ certified by an energy consultant; C) an appraisal report indicating the post-improvement energy efficiency of the property; or D) MEC 92 compliance documented by one of the following: a) building permit in states with mandatory state energy code, $b$ ) preapproved prescriptive certification, $c$ ) assurance from an energy consultant or a builder. ${ }^{88}$

Moreover, the Freddie Mac EEMs guidelines allow a broader range of energy-efficient improvements than other EEMs. Regarding Freddie Mac's definition of "energy-efficient property and conservation items," the Florida Solar Energy Center notes the following:

Section 2214, "Energy-Efficient Properties," defines these properties as follows: An energy-efficient property uses cost-effective design, materials, equipment, and site orientation to conserve nonrenewable fuels. Implicit in this definition is proper design and installation of materials and equipment consistent with the climate in the area. (This

\footnotetext{
${ }^{84}$ Telephone conversation with Patricia O'Loughlin, June 11, 1999.

${ }^{85}$ From a telephone interview with David Carey, Fannie Mae Home Improvement Loans Division, May 21, 1999.

${ }^{86}$ Telephone conversation with John Hemschoot, Freddie Mac, July 1, 1999.

${ }^{87}$ Freddie Mac's Form 70A is a two part form (formerly the Energy Addendum to the Residential Appraisal Report), the first part of which must be completed by an energy consultant documenting their valuation of the energy efficiency features of the given home. Part two is not required for an EEM but may be completed by the appraiser or energy consultant documenting the calculated savings expected from the energy efficiency features.

88 "Financing Energy Efficiency: A Handbook for Lenders," by Randy Martin, Iowa Energy Center, cites the Freddie Mac publication, SingleFamily Seller/Servicer Guide, Volume 1, May 5, 1999; chapter 37.16.
} 
definition could also include the use of alternative equipment to generate or supplement an individual property's power needs, such as a windmill or solar panel that generates electricity. ${ }^{89}$

Although Freddie Mac's guidelines for EEMs have been readily available to lenders (i.e., referred to in the Single Family Seller/Service Guide as "sellers") since early 1998, there appears to be no means to determine how the lenders might have interpreted the guidelines, or how often they might have used them. Currently, Freddie Mac does not have information available on the number of EEMs given by the lenders.

\section{National Primary Lenders with Energy-Efficient Mortgage Programs}

Currently, several national lenders are providing EEMs, which are listed below. After performing a search, the author is unaware of any other ongoing national EEM programs as of January 2000.

\section{Chase Manhattan Mortgage Corporation}

Chase Manhattan Mortgage is currently offering an energy-efficient mortgage for new construction based on the $2 \%$ stretch ratios with the added incentive of discounts on closing costs. ${ }^{90}$ Chase's EEM product is available nationwide, with more active promotion reported in some states. ${ }^{91}$ Chase became an ENERGY STAR Mortgage partner in 1997. Chase's EEMs emphasis is more on the builder market than on the borrower market. To qualify a home for an ENERGY STAR Mortgage product, the Chase EEM requires a certification of energy efficiency through an EPA-approved prescriptive method, a HERS, or a sampling protocol using either method.

\section{Countrywide Home Loans}

Countrywide Home Loans also offers a $\%$ stretch ratio EEM product nationwide, which is marketed through the ENERGY STAR Mortgage program. Countrywide's EEM requires qualification of energy efficiency by means of EPA's prescriptive process, a HERS, or a system of sampling. According to an EPA official, the Countrywide EEM does not offer a closing cost discount, but it does waive fees for the tax service contract and the credit report. Also, local Countrywide offices may provide additional incentives. According to a Countrywide official, the Countrywide Builder Division is actively involved in the promotion of EEMs, but the EEMs activities of the local Countrywide offices are not limited to the builder market. ${ }^{92}$

\section{GMAC}

An official with GMAC Mortgage reports that the company financed "about 5,000" energy-efficient mortgages in $1998 .{ }^{93}$ GMAC has been providing $2 \%$ stretch ratio EEMs since 1986. In December 1998, GMAC launched a new EEM. Marketed directly to builders as the "Solar Energy Built Homes Program" this EEM product emphasizes solar energy installations (see also section IV, 1. Federally Chartered Lenders). Available for new construction only, this EEM is an "enhancement" of the "Fannie Mae conforming fixed rate and seven-year balloon products." "The enhancement allows "GMAC to consider increased qualifying ratios for the purchasers of energy-efficient homes based on the monthly reduction of

\footnotetext{
${ }^{89}$ The quotation is from "Financing Energy Efficiency: A Handbook for Lenders," by Randy Martin, Iowa Energy Center, which references the Freddie Mac publication Single-Family Seller/Servicer Guide url: http://www.fsec.ucf.edu/ratings/LndrHndBk/FRMExA.htm. Date accessed: November 16, 1999.

${ }^{90}$ From information provided by the EPA ENERGY STAR Mortgage Program Manager, Carol May. July 30, 1999.

${ }^{91}$ State energy Officials in Florida, Maine, Michigan, and Utah report that Chase representatives are actively promoting EEMs.

${ }_{92}^{92}$ Hilary Hanel, Portfolio Products Manager, Countrywide Home Loans, telephone conversation, August 3, 1999

${ }^{93}$ GMAC Mortgage National Business Development Division, June 16, 1999. For further information regarding these loan programs, see www.gmacmortgage.com and click on the branch locator to find the number of your local GMAC Mortgage office.

${ }^{94}$ GMAC Mortgage Inter-Office Memorandum, from Eileen Mitchell, GMAC Mortgage Credit Policy; "Energy Efficient Enhancements," dated December 16, 1998, and indexed as CP98-167.
} 
their EEMs. The GMAC EEM is available nationwide with the majority of mortgages occurring in Arizona (e.g., Civano, a sustainable residential development of 2,600 homes in Tucson ${ }^{95}$ ).

\section{Norwest Mortgage, Inc.}

In 1996 Norwest Mortgage, Inc. launched a nationwide, cooperative energy-efficient mortgage effort with the EPA ENERGY STAR Homes program. Norwest's EEM was marketed through a toll-free phone number, but after less than a year it became inactive. ENERGY STAR Mortgages are now marketed though local Norwest branches. Various focused interviews report Norwest's EEM activity continuing as the standard 2\% stretch ratio in Florida, Iowa, New Jersey, Ohio, and Pennsylvania. ${ }^{96}$ Currently in these states Norwest representatives are actively marketing EEMs to builders, and promoting their use by working with local interests, such as non-profit HERS providers, state energy offices, and utility companies.

In Florida, Ohio, and Pennsylvania the Norwest product, which offers closing cost discounts in addition to the $2 \%$ stretch ratio, is an ENERGY STAR Mortgage and requires either a HERS, builder option package, or a sampling method to qualify. In all areas, according to a Norwest official, the field representatives see immediate advantages in promoting EEMs as "a way to get in with more builders." Apparently, it is a niche approach to covering the market through all sizes of builders.

\section{Lincoln Service Mortgage}

Edison Electric Institute's (EEI) E Seal program is working with a national lender, Lincoln Service Mortgage, to offer an EEM as a component of their program. Lincoln Service Mortgage offers an EEM that finances $100 \%$ of cost-effective energy-efficiency upgrades, without increasing the down payment or private mortgage insurance. Lincoln Service Mortgage allows the full cost of energy-efficiency upgrades to be financed through the mortgage and recognizes and warrants the full value of the upgrades in the mortgage. This EEM removes financing and institutional barriers that can inhibit the purchase of more energy-efficient and environmentally responsive homes. Lincoln Service Mortgage offers this product nationwide, but only through affinity marketing partnerships with electric utilities that have E Seal certified programs. Lincoln Service Mortgage relies on the sponsoring electric utility for the value of the cost-effective energy efficiency upgrades, which can be provided by the utility, or a qualified energy consultant or HERS report. In addition to the $100 \%$ financing of cost-effective energy efficiency upgrades, Lincoln Service Mortgage, through the sponsoring electric utility, offers preferential mortgage products, with interest rates $1 / 8$ to $1 / 4$ percent below prevailing national rates and reduced closing costs or zero origination fee.

\section{HERS and Other Organizations' Activities}

\section{HERS Council, Voluntary National Ratings Guidelines and National Association of State Energy Officials / Residential Energy Services Network Guidelines}

In 1992 the DOE was directed (via section 102 of EPACT, "Residential Energy Efficiency Rating Guidelines,") to issue voluntary guidelines to encourage uniformity in systems for rating the annual energy efficiency of residential buildings. The guidelines were to be developed in consultation with various federal agencies and private entities interested in residential energy-efficiency ratings. The legislation specified that the secretary of HUD, the secretary of VA, representatives of existing home energy rating programs, and other appropriate persons should be consulted.

\footnotetext{
${ }^{95}$ The Building America program, one of DOE's Office of Building Technology, State and Community Programs, provided technical assistance to Civano. Model homes were tested to exceed high community building standards and provide for guaranteed savings. From www.civano.com. Date accessed: August 28, 1999.

${ }^{96}$ Telephone interviews with the relevant state energy officials, and with Dan Schmidt, Director of Norwest's National Builder Division, June 7, 1999.
} 
According to the directive, the guidelines should establish protocols and procedures for:

- Certification of the technical accuracy of building energy analysis tools used to determine energy-efficiency ratings ${ }^{97}$

- Training of rating personnel

- Data collection and reporting

- Quality control

- Monitoring and evaluation.

The guidelines were also to account for local climate conditions and construction practices, solar energy collected on site, and the benefits of peak load shifting techniques. Additionally, the guidelines were "not to discriminate among fuel types." The concept of not discriminating among fuel types was not further explained in the legislation, and is sometimes referred to as the "fuel neutrality issue." The fuel neutrality issue has been the cause of controversy among stakeholders, and is closely related to the rating method ${ }^{98}$ and to the concepts of source and site energy use.

In response to the EPACT directives, DOE collaborated with hundreds of stakeholders and organizations through the HERS Council including the National Association of State Energy Officials (NASEO) and HERS providers - many of whom had been meeting regarding HERS since about 1987. Based on input from all the stakeholders, on July 25, 1995, DOE issued for public comment a Notice of Proposed Rulemaking on voluntary guidelines.

Most of the comments DOE received on the proposed rule were readily resolved. But the issue of "fuel neutrality" was not easily incorporated into the rule. "Fuel neutrality" involved interpretation of the requirement that the rule not "discriminate among fuel types" for which the EPACT legislation provided no clarification. Yet, in spite of an intensive effort by DOE to work with both the electric and natural gas industries, a definition regarding fuel neutrality was not resolved and remains hotly disputed.

Initially, using DOE technical resources, the HERS Council issued guidelines and then DOE issued the Notice of Proposed Rulemaking for public comment; however, the fuel neutrality issue remains disputed. Moreover, HERS, EEMs, and guidelines for their uniformity have continued to develop. At the state and local level, HERS activities can be found in all but three states. State and local rating systems have been moving ahead under the jurisdiction of states and the oversight of national professional and industry organizations. The HERS industry members of NASEO and the Residential Energy Services Network (RESNET) have adopted guidelines similar to the draft guidelines produced by DOE. The document National NASEO/RESNET Home Energy Rating System Guidelines, dated September 19, 1999, parallels the draft guidelines issued by DOE for public comment, and was similar to the HERS Council guidelines. Joint efforts by NASEO and RESNET have also produced accreditation standards for using HERS in mortgage lending. The NASEO/RESNET accreditation standards relied heavily upon the accreditation standards produced by the HERS Council. The NASEO/RESNET group is still struggling with the definition of fuel neutrality, but the market is moving forward with the industry guidelines.

In summary, the technical work that DOE and the HERS Council accomplished has been adopted in the NASEO/RESNET guidelines document. Except for the fuel neutrality issue, these guidelines successfully addressed the items called for in EPACT to the satisfaction of the HERS Council and NASEO/RESNET.

\footnotetext{
${ }^{97}$ Judkoff, R., J. Neymark, Home Energy Rating System Building Energy Simulation Test (HERS BESTEST). Volumes 1 and 2. NREL/TP-4727332. Nov. 1995 .

${ }^{98}$ The rating method is the means by which energy use is converted to a rating score.
} 
Moreover, the proposed outcome of a DOE final voluntary HERS rule was to facilitate the development of a nationwide industry, to provide consistent information to residents, and to support energy-efficiency financing. This has been achieved without a final rule through the public/private partnership of DOE, industry, and the financial community. HERS are now available in 47 states; they are generally consistent in content, and energy-efficiency financing is growing steadily. DOE has not issued a final rule on HERS.

\section{Energy Rated Homes of America}

Energy Rated Homes of America (ERHA) is a non-profit 501 [c] [3] membership organization that provides consumers with access to preferred financing for making their homes more affordable through energy efficiency. ERHA seeks to be the national association of HERS providers, and attempts to strengthen such programs as ENERGY STAR Homes and attract more mortgage partners to offer preferred financing for energy-efficient homes. As of summer 1999, ERHA has expanded the number of member states to 16: Alaska, Arkansas, Colorado, Florida, Illinois, Indiana, Iowa, Louisiana, Michigan, Mississippi, Missouri, Nevada, Oregon, Utah, Vermont, and Wisconsin. ${ }^{99}$ ERHA-affiliated programs include: Energy Rated Homes of Alaska, Energy Rated Homes of Arkansas (Arkansas and Missouri), Energy Rated Homes of Colorado, CHEERS (one of several California HERS providers), Energy Rated Homes of Iowa, Energy Rated Homes of Louisiana, Energy Rated Homes of the Midwest (Indiana and Michigan), Energy Rated Homes of Mississippi, Energy Rated Homes of Nevada, Energy Rated Homes of Oregon, Energy Rated Homes of the South (Alabama, Georgia, North Carolina, and South Carolina), Energy Rated Homes of Utah, Energy Rated Homes of Vermont, Energy Wise Homes of Illinois, Florida Energy Gauge Program, and Wisconsin Energy Conservation Corporation. ${ }^{100}$ Other ERHA-affiliated states include: Connecticut, Maine, Massachusetts, Montana, New Hampshire, New York, and Ohio. ${ }^{101}$

\section{National Home Energy \& Resources Organization}

National Home Energy and Resources Organization (National-HERO) is a private sector corporation based in Richmond, Virginia. National HERO has trained and certified approximately 400 raters in over 35 states since 1995, and currently can offer HERS and related services in 40 states and the District of Columbia. These states include: Alabama, Arkansas, Arizona, California, Colorado, Connecticut, Delaware, Florida, Georgia, Illinois, Indiana, Iowa, Kansas, Kentucky, Maine, Maryland, Massachusetts, Michigan, Minnesota, Mississippi, Missouri, Nebraska, Nevada, New Hampshire, New Jersey, New York, North Carolina, Ohio, Oklahoma, Oregon, Pennsylvania, Rhode Island, South Carolina, Tennessee, Texas, Utah, Virginia, Washington, and West Virginia. ${ }^{102}$ The number of raters per state varies widely with some states having more rater coverage than others. National HERO is nationally accredited and provides plan review and heating, ventilating and air conditioning systems sizing; program marketing and management services; and training for lenders, real estate professionals, raters, utilities, contractors, and builders. National HERO offers heating/cooling cost guarantees on new homes. National HERO also manages the Virginia Home Energy Rating Organization, the HERS provider organization in the pilot state of Virginia.

\section{Edison Electric Institute}

The Edison Electric Institute (EEI) is an industry association of shareholder-owned electric utilities. EEI's E Seal program is a self-supported green-building initiative and energy-efficiency financing program that certifies utility programs for both new and existing homes via energy-efficient and

\footnotetext{
${ }^{99}$ Energy Rated Homes of America website, url:http://www.erha.com. Date accessed: August 28, 1999.

${ }^{100}$ From Energy Rated Homes web site, url: http://www.erha.com. Date accessed: August 27, 1999.

${ }^{101}$ E-mail from Steve Baden, RESNET, November 18, 1999.

${ }^{102}$ National HERO web site, url: http://www.national-hero.com. Date accessed: November 12, 1999.
} 
environmental criteria. An E Seal-certified program must meet specific energy-efficiency criteria and incorporate features for indoor air quality, water quality and conservation, home waste management, and construction waste reduction. E Seal offers financing that can eliminate or reduce the first cost barrier to higher levels of energy efficiency.

E Seal guarantees that certified residential construction programs exceed MEC 1992 by a minimum of $10 \%$. However, the program gives incentives for utilities that adopt criteria resulting in houses that perform 20\% to 30\% better than MEC 1992. Since its launch in 1994, E Seal utilities and their buildings have built 155,000 new homes that are 20\% to 30\% more efficient than MEC 1992. EEI estimates the savings are \$26 million and 312 million $\mathrm{kWh}$ each year. ${ }^{103}$

An important component of the E Seal program is the financing of residential energy-efficiency upgrades. The E Seal Energy-Efficiency Mortgage is available through Lincoln Service Mortgage and utilities with E Seal-certified programs and offers the following benefits: ${ }^{104}$

- Finances the purchase of new homes with E Seal upgrades, or refinances existing homes while adding E Seal upgrades

- Finances $100 \%$ of the E Seal upgrades, the value of which is recognized and warranted by the lender

- Requires no additional down-payment, no increase in mortgage insurance obligation or requalification for a higher mortgage, thus providing customers lower monthly housing costs

- Offers maximum qualifying ratios that are 5\% better than standard ratios and 3\% better than regular EEMs, allowing buyers to qualify for $15 \%$ to $20 \%$ larger mortgages

- Offers preferential mortgage products, with lower than prevailing market interest rates and closing costs, i.e. zero origination fee

- Provides customer service performance guarantees regarding application approvals and adherence to the designated closing date

- Takes applications over toll-free phone lines.

The E Seal program was designed to be sufficiently flexible that participating utilities can address a wide range of energy and environmental issues in ways that best suit their overall corporate, demand-sidemanagement, marketing, and consumer program goals. ${ }^{105}$

\section{HERS Activities In States Other Than DOE Pilot States}

To assess HERS activities in states other than the seven DOE pilot states, focused interviews were conducted with stakeholders including SEO officials between April and August 1999. Interviews revealed that ratings programs have been developed in three states that were neither DOE pilot states nor SEP-grantee states - Arizona, Louisiana, and Texas. ${ }^{106}$ In addition, the following six non-pilot states, which received SEP funding, have developed independent HERS programs: Florida, Idaho, Kansas, Nebraska, Washington, and Wisconsin. Beyond the aforementioned states, these 10 states have operating HERS programs: Indiana, Illinois, Iowa, Michigan, Nevada, New Mexico, Ohio, Oregon, Tennessee, and Utah. Additionally, another 10 states $^{107}$ indicate that they have HERS programs in development or in transition from a pilot program to a state-wide program.

\footnotetext{
${ }^{103}$ Memo from Tom Farkas, EEI “Comments on Report” January 31, 2000.

${ }^{104}$ From a document entitled Energy Efficiency Mortgage provided by EEI's Tom Farkas, on August $16,1999$.

${ }^{105}$ From a document entitled E Seal Certification provided by EEI's Tom Farkas, on August 16, 1999.

${ }^{106}$ See Table 1 for additional details on state programs.

${ }^{107}$ The 10 states are Connecticut, Delaware, Hawaii, Maine, Maryland, Massachusetts, New Hampshire, New York, Rhode Island, and Wyoming.

From focused interviews conducted in April - August 1999.
} 
The focused interviews also revealed that the independent HERS program development is happening both separately and in relation to the development of HERS programs in pilot states and SEP grantee states. In relation to current HERS programs, reciprocity agreements are being negotiated and signed (e.g., between Ohio and Michigan), existing local HERS providers are expanding to regional levels (e.g., Indiana and Vermont), and HERS programs in one state are helping other states to develop their own programs (e.g., Mississippi and North Carolina).

Those activities occurring separately from the activities of the pilot states and SEP grantee states involve EEMs. Higher numbers of EEMs are reported in several non-pilot, non-SEP-grantee states than in the pilot or SEP grantee states. Through focused interviews with SEOs, it appears that much of this EEM activity can be attributed to aggressive promotion of the ENERGY STAR Homes program. Apparently, both EPA and the homebuilding sector are marketing energy-efficient options for new residential construction, which is promoting EEMs. 


\section{Bibliography}

Adams, T. (June 18, 1999). Telephone interview. Science, Technology, and Energy Division, Montgomery, AL.

Adams III, T.C. (April 23, 1999). Telephone interview. North Carolina Department of Commerce, Energy Division, Raleigh, NC.

Baden, S. (May 20, 1999). Telephone interview. RESNET, Oceanside, CA.

Baldauf, R. (May 14, 1999). Telephone interview. South Carolina Energy Office, Columbia, SC.

"Builder Caught in Crossfire over Energy Star Test Protocols." (July 1999). Energy Design Update. Vol. 19, No. 7.

Butler, S. (June 17, 1999). Telephone interview. Kansas Department of Commerce and Housing, Housing Development Division, Topeka, KS.

Burton, R. (June 2, 1999). Telephone interview. National Association of Home Builders, Washington, DC.

Byrd, W. (May 25, June 21, Aug. 17, and Sept. 27, 1999). Telephone interviews. Department of Natural Resources, Energy Division, Baton Rouge, LA.

Carey, D. (May 21, 1999). Telephone interview. Fannie Mae, Washington, DC.

Carter, B. (May 18 and Oct. 15, 1999). Telephone interviews. Washington State University Energy Program, Olympia, WA.

"Civano." (Last modified Nov. 3, 1999). Civano Homes online, http://www.civano.com. Accessed August 28, 1999.

Christianson, K. (May 14, 1999). Telephone interview. North Dakota Division of Community Services, Bismarck, ND.

Clinton, C.J. (April 29, 1999). Telephone interview. D.C. Energy Office, Washington, DC.

Collins, B. (March 10, 1999). Interview. Energy Rated Homes of Alaska, Anchorage, AK.

Collins, N.E.; Farhar, B.C.; Babiuch, W.M.; Eckert, J. (August 1994). A Plan for Evaluating Alternative Approaches to Financing Energy Improvements in Housing. Final Draft. NREL/TP-461-6688. Golden, CO: National Renewable Energy Laboratory, 147 pp.

Connors, J. (June 17, 1999). Telephone interview. State Planning Office, Office of Community Development, Augusta, ME.

DeVol-Glowinski, C. (April 23, 1999). Telephone interview. Indiana Department of Commerce, Indianapolis, IN. 
Edmunds, M. (March 24, 1999). Interview. Colorado Housing and Finance Authority, Energy Rated Homes of Colorado, Denver, CO.

Eklund, K. (June 16, 1999). Telephone interview. Idaho State Energy Office, Boise, ID.

"Energy Rated Homes of America." (Last modified Oct. 23, 1999). Energy Rated Homes of America online, http://www.erha.com. Accessed August 28, 1999.

"Energy Star Homes Program." (Last modified June 17, 1999). U.S. Environmental Protection Agency online, http://yosemite.epa.gov/appd/eshomes/eshomes.nsf. Accessed July 26, 1999.

Faesy, R. (Feb. 19, 1999 and Sept. 17, 1999). Interview and telephone interview. Energy Rated Homes of Vermont, Burlington, VT.

Fairey, P. (June 15, June 30, July 13, and Aug. 1, 1999). Telephone interviews. Florida Solar Energy Center, Cocoa, FL.

Farhar, B.C.; Collins, N.E., Walsh, R.W. (May 1997). Case Studies of Energy Efficiency Financing in the Original Five Pilot States, 1993-1996. NREL/TP-550-22355. Golden, CO: National Renewable Energy Laboratory, 362 pp.

Farhar, B.C.; Collins, N.E.; Walsh, R.W. (October 1996). Linking Home Energy Rating Systems with Energy Efficiency Financing: Progress on National and State Programs. NREL/TP-460-21322. Golden, CO: National Renewable Energy Laboratory, 25 pp.

Farhar, B.C. (2000). HERS/EEMs Pilot States Program Report. Golden, CO: National Renewable Energy Laboratory.

Farhar, B.C., J. Eckert (Sept. 1993). Energy Efficient Mortgage and Home Energy Ratings Systems: A Report on the National's Progress. NREL/TP-461-5478. Golden, CO: National Renewable Energy Laboratory. 265 pp.

Farkas, T. (June 4, 1999). Telephone interview. Edison Electric Institute, Washington, DC.

Farkas, T. (Aug. 16, 1999, Jan. 31, 2000, and Feb. 7, 2000). Memorandums. Edison Electric Institute, Washington, DC.

Federal Home Loan Mortgage Corporation. Single-Family Seller/Servicer Guide, Vol. 1. (May 1999). Washington, DC: Freddie Mac; chapter 37.16.

Finneran, B. (Aug. 16, 1999). Telephone interview. Department of Veterans Affairs, Washington, DC.

Folkman, J. (Oct. 3, 1999). Telephone interview. Home Builders Association of New Mexico, Albuquerque, NM.

Fortney, M. (May 17, 1999). Telephone interview. Pennsylvania Housing Research Center, University Park, PA.

Foster, T. (April 23, 1999). Telephone interview. Energy Bureau, Energy and Geological Resources Division, Des Moines, IA. 
Fritts, C. (June 3, 1999). Telephone interview. American Gas Association, Washington, DC.

Gardner, J. (Feb. 16, 1999). Interview. Energy Rated Homes of Arkansas, North Little Rock, AR.

Gardstein, C. (June 3, 1999). Telephone interview. HERS Council, Washington, DC.

Glenn, M. (May 27, 1999). Telephone interview. Office of Energy Services, Salt Lake City, UT.

Gohman, C. (June 18, 1999). Telephone interview. Arizona Energy Office, Phoenix, AZ.

Gouffray, J. (May 14, 1999). Telephone interview. South Carolina Energy Office, Columbia, SC.

GMAC Mortgage. (June 16, 1999). Telephone interview. National Business Development Division.

Green, B. (June 22, 1999). Telephone interview. Department of Environmental Quality, Helena, MT.

Groberg, R. (January 28, 2000). Memorandum. U.S. Department of Housing and Urban Development, Washington, DC.

Groves, R. (June 17, 1999). Telephone interview. Rhode Island State Energy Office, Providence, RI.

Guerard, M. (June 16, 1999). Telephone interview. Conservation Services Group, West Borough, MA.

Haake, M. (June 22, 1999). Telephone interview. Department of Natural Resources, Division of Energy, Jefferson City, MO.

Harding, S. (May 14, 1999). Telephone interview. Governor's Office of Economic Development, Pierre, SD.

Hattery, T. (May 25, 1999). Telephone interview. Maryland Energy Administration, Annapolis, MD.

Hemschoot, J. (June 2, 1999). Telephone interview. Federal Home Loan Mortgage Corporation (Freddie $\mathrm{Mac})$.

Herholdt, J. (May 18, 1999). Telephone interview. West Virginia Development Office, Energy Efficiency Program, Charleston, WV.

Hester, D. (1999). Chase Manhattan and the Energy Star Home Mortgage Program. Edison, NJ: Chase Manhattan Mortgage.

Hodgson, M. (Feb. 9 and Aug. 16, 1999). Interview and telephone interview. ConSol, Inc., Stockton, CA.

Hoffman, D. (May 14, 1999). Telephone interview. Wyoming Business Council, Energy Minerals Division, Cheyenne, WY.

Holman, V. (July 7, 1999). Telephone interview. U.S. Department of Housing and Urban Development Federal Housing Authority, Richmond, VA.

“Hudclips." (Last modified: unknown). U.S. Department of Housing and Urban Development's Client Information and Policy System online, http://www.hudclips.org/cgi/index.cgi. 
Jansen, M. (May 21, 1999). Telephone interview. Energy Rated Homes of America, Indianapolis, IN.

Johanson, A. (June 19, 1999). Telephone interview. Connecticut Office of Policy and Management, Hartford, CT.

Jones, P. (June 7, 1999). Telephone interview. Florida Energy Extension Service, University of Florida, Gainesville, FL.

Judkoff, R.; Neymark, J. (February 1995). International Energy Agency Building Energy Simulation Test (BESTEST) and Diagnostic Method. NREL/TP-472-6231. Golden, CO: National Renewable Energy Laboratory.

Kaluza, P. (April 23 and Sept. 22, 1999). Telephone interviews. Alaska Housing Finance Corporation, Anchorage, AK.

Kramer, A. (June 16, 1999). Telephone interview. Oregon Housing and Community Services, Salem, OR.

Lee, D. (June and December 6, 1999). Interviews. EPA’s ENERGY STAR Homes Program, Washington, DC.

Lopez, F. (May 26 and Aug. 11, 1999). Telephone interviews. Texas Energy Conservation Office, Austin, TX.

Lowrie, C. (March 5, 1999). Interview. Virginia H.E.R.O., Richmond, VA.

Lowrie, S. (May 24, 1999). Telephone interview. National H.E.R.O., Richmond, VA.

Lyle, J. (Sept. 17 and Nov. 4, 1999). Telephone interviews. Tennessee Valley Authority, Nashville, TN.

Mape, R. (May 14, 1999). Telephone interview. Department of Environmental Protection, Harrisburg, PA.

Marley, J. (April 23, 1999). Telephone interview. Illinois Department of Commerce and Community Affairs, Springfield, IL.

Masland, L. (June 16, 1999). Telephone interview. Department of Economic Development, Division of Energy Resources, Boston, MA.

May, C. (July 30, 1999). “Key Features of Energy Star Mortgage Products.” Draft. Washington, DC: U.S. Environmental Protection Agency.

McNeil, D. (June 17, 1999). Telephone interview. Nevada State Energy Office, Department of Business and Industry, Carson City, NV.

Meunier, M. (May 27, 1999). Telephone interview. Division of Energy and Public Benefits, Madison, WI.

Mitchell, E. (Dec. 16, 1998). Interoffice memorandum, CP98-167. GMAC Mortgage.

Murphy, J. (May 14, 1999). Telephone interview. North Dakota Division of Community Services, Bismarck, ND. 
National Collaborative on Home Energy Rating Systems and Mortgage Incentives for Energy Efficiency. (March 1992a). A National Program for Energy-Efficient Mortgages and Home Energy Rating Systems: A Blueprint for Action, Final Report of the National Collaborative. Review Draft. NREL/TP-261-4677. Washington, DC: National Renewable Energy Laboratory, 37 pp.

- (March 1992b). Going National with HERS and EEMs: Issues and Impacts, The Collected Papers of the National Collaborative. NREL/TP-261-4706. Washington, DC: National Renewable Energy Laboratory, 209 pp.

"National H.E.R.O." (Last modified March 3, 1999). National Home Energy \& Resources Organization, Inc., online, http://www.national-hero.com. Accessed August 28, 1999.

O’Loughlin, P. (May 14, 1999). Telephone interview. Fannie Mae, Washington, DC.

Oliphant, C. (May 24, 1999). Telephone interview. Tennessee Department of Economics and Community Development, Energy Division, Nashville, TN.

Osterman, J. (April 2 and Sept. 15, 1999). Telephone interviews. Nebraska State Energy Office, Dollar and Energy Saving Program, Lincoln, NE.

Papesh, C. (June 23, 1999). Telephone interview. Energy Rated Homes of Iowa, Elberon, IA.

Perry, L. (March 8, 1999). Interview. Energy Rated Homes of Mississippi, Inc., Jackson, MS.

Ploger, J. (May 25, 1999). Telephone interview. Kansas Corporation Commission, Topeka, KS.

Robertson, E. (April 23, 1999). Telephone interview. Georgia Environmental Facilities Authority, Atlanta, GA.

San Filippo, N. (July 20, 1999). Telephone interview. Colorado Housing and Finance Authority, Denver, CO.

Sarver, J. (May 25, 1999). Telephone interview. Energy Resources Division, Lansing, MI.

Schachter, D. (May 14, 1999). Telephone interview. Governor's Office of Energy and Community Services, Concord, NH.

Schmidt, D. (June 7, 1999). Telephone interview. Norwest Mortgage, National Builder Division.

Shon, C. (April 23, 1999). Telephone interview. Department of Business Economic Development and Tourism, Honolulu, HI.

Smisson Jr., C.T. (June 17, 1999). Telephone interview. State Energy Office, Dover, DE.

Smith, T. (June 17, 1999). Telephone interview. Office of Energy Efficiency, Columbus, OH.

Spitzer, N.A. (March 14, 1996). Circular Letter, TAM-96-01. U.S. Department of Housing and Urban Development, Tampa, FL.

Stapleton, J. (May 25, 1999). Telephone interview. Kentucky Division of Energy, Frankfort, KY. 
Streff, J. (May 25, 1999). Telephone interview. Minnesota Department of Commerce, Energy Division, St. Paul, MN.

Tait, J. (June 3, 1999). Telephone interview. Florida State Energy Office, Tallahassee, FL.

Threlkel, C. (Feb. 8, 1999). Interview. California Energy Commission, Sacramento, CA.

Trujillo, H. (May 18 and 26, 1999). Telephone interviews. Energy Conservation and Management Division, Santa Fe, NM.

U.S. Environmental Protection Agency Energy Star Program. (July 1999). Energy Star Technical Verification: Home Energy Ratings Systems (HERS) Ratings vs. Builder Option Packages, Based on Sample Home in Columbus, Ohio. Draft. Washington, DC: EPA Energy Star Program.

U.S. Department of Housing and Urban Development, Federal Housing Administration. (May 24, 1993). Mortgagee Letter, 93-13. Washington, DC.

. (Aug. 24, 1993). Mortgagee Letter, 93-26. Washington, DC.

—. (Oct. 22, 1993). Mortgagee Letter, 93-35. Washington, DC.

. (March 15, 1995). Mortgagee Letter, 95-12. Washington, DC.

. (Oct. 6, 1995). Mortgagee Letter, 95-46. Washington, DC.

- (Aug. 26, 1996). Mortgagee Letter, 96-46. Washington, DC.

-. (April 1, 1997). Mortgagee Letter, 97-10. Washington, DC.

-. (May 20, 1997). Mortgagee Letter, 97-22. Washington, DC.

. (June 10, 1997). Mortgagee Letter, 97-26. Washington, DC.

(Jan. 2, 1998). Mortgagee Letter, 98-2. Washington, DC.

Weiss, M. (May 17, 1999). Telephone interview. New Jersey Board of Public Utilities, Division of Energy, Newark, NJ.

Williams, B. (June 22, 1999). Telephone interview. Oklahoma Department of Commerce, Division of Community and Economic Development, Oklahoma City, OK.

Wilson, V. (Aug. 3, 1999). Electronic mail. Norwest Mortgage, National Builder Division. 


\section{Appendix A \\ List of Contact Information}

The following pages contain a list of individuals who have provided information in the preparation of this report and have agreed to be contacted for more information about state-specific, program-specific or other specialized information.

Terri Adams

Energy Conservation Section Chief

Science, Technology and Energy Division

Alabama Department of Economic and

Community Affairs

401 Adams Avenue

PO Box 5690

Montgomery, AL 36103-5690

T.C. Adams III

Director, North Carolina State Energy Division North Carolina Department of Commerce

1830A Tillery Place

Raleigh, NC 27604

Kelly Aker

The Community of Civano

10501 E. Seven Generations Way

Tucson, AZ 85747

Randy Altergott

Technical Consultant

Tucson Electric Power

PO Box 711

220 West 6th Street

Tucson, AZ 85702

Steve Baden

Executive Director

Residential Energy Services Network

PO Box 4561

Oceanside, CA 92052

Rick Baldauf

Program Coordinator

South Carolina Energy Office

1201 Main Street

Suite 820

Columbia, SC 29201
Don Best

Editor

Energy Design Update

65 Hallwood Drive

Surry, NH 03431

Frank Bishop

Executive Director

National Association of State Energy Officials

1414 Prince Street

Suite 200

Alexandria, VA 22314

Ron Burton

Assistant Staff Vice President,

Construction Codes and Standards

Regulator and Legal Affairs Division

National Association of Home Builders

1201 15th St. NW

Washington, DC 20005

Stan Butler

Program Manager, Housing Development

Division

Kansas Department of Commerce and Housing

700 SW Harrison Street

Suite 1300

Topeka, KS 66603-3712

Wade Byrd

Supervisor, Energy Rated Homes of Louisiana

Energy Division

Department of Natural Resources

PO Box 44156

Baton Rouge, LA 70804-4156

David Carey

Director of Energy Finance

Fannie Mae

3900 Wisconsin Avenue, NW

MS 2H5W/02

Washington, DC 20016 
Brian Carey

Mortgage Bankers Association of America

112515 th Street, NW

Washington, DC 20005

Bruce Carter

Building Science Specialist

Washington State University Energy Program

925 Plum Street, SE, Bldg \# 4

Olympia, WA 98504-3173

Kim Christianson

Energy Program Manager, Energy Programs

North Dakota Division of Community Services

State Capitol, 14th Floor

600 East Boulevard Avenue

Bismarck, ND 58505-0170

Charles J. Clinton, Director

D.C. Energy Office

2000 14th Street, NW

Suite 300E

Washington, DC 20009

Barbara Collins

Executive Director and Western Regional

Manager for ERH America

Energy Rated Homes of America

P.O. Box 112642

Anchorage, AK 99511

Blaine Collison

Certification Program Manager

EPA Energy Star Homes Program

401 M Street, SW

$\mathrm{M} / \mathrm{S}$ 6206J

Washington, DC 20460

Jim Connors

Senior Policy Analyst, Office of Community

Development

State Planning Office

State House Station \#38

Augusta, ME 04333

Dean Daetwyler

Senior Loan Specialist

USDA-RHS Single Family Housing Guaranteed

Loans Division

1400 Independence Avenue, SW

Washington, DC 20250-0761
Cheryl DeVol-Glowinski

Director of Energy Policy Division

Indiana Department of Commerce

One North Capitol

Suite 700

Indianapolis, IN 46204-2288

Debbie Dickinson

Loan Specialist

Department of Veterans Affairs

1800 G St., NW

Room 533

Washington, DC 20420

Megan Edmunds

Program Manager

Colorado Housing and Finance Authority

Energy Rated Homes of Colorado

1981 Blake St.

Denver, CO 80202

Ken Eklund

Senior Conservation Specialist, Idaho Energy

Division

Idaho Department of Water Resources

1301 N. Orchard Street

PO Box 83720

Boise, ID 83720-0098

Richard Faesy, Development Director

Energy Rated Homes of Vermont

255 Champlain St

Burlington, VT 05401

Philip Fairey, Deputy Director

Florida Solar Energy Center

1679 Clearlake Rd

Cocoa, FL 32922-5703

Tom Farkas

Manager of Residential Programs

Edison Electric Institute

701 Pennsylvania Avenue, NW

Washington, DC 20004

Jon Ferchen

Media Relations Specialist

Norwest Mortgage, Inc

1 Home Campus

Des Moines, IA 50328-0001 
Bob Finneran

Assistant Director of Loan Policy and Valuation Department of Veterans Affairs

1800 G St., NW

Room 533

Washington, DC 20420

Jim Folkman

Executive Vice President

Home Builders Association of New Mexico

5931 Office Blvd, NW

Suite 2

Albuquerque, NM 87109

Mark Fortney

Assistant Director

Pennsylvania Housing Research Center

219 Sackett Building

University Park, PA 16802

Tami Foster

Program Planner III, Energy and Geological

Resources Division

Energy Bureau

East 9th \& Grand Avenue

Des Moines, IA 50319

Charles Fritts

Vice President

American Gas Association

400 N. Capitol Street, NW

Washington, DC 20001

Jeremiah Gardner

Executive Director

Energy Rated Homes of Arkansas

JFK Blvd, Suite C-1

North Little Rock, AR 72116

Cynthia Gardstein

Executive Director of HERS Council

HERS Council

1331 H St., NW

Suite 1000

Washington, DC 20005

Michael Glenn

Director of Office of Energy Services

Utah Office of Energy Services

324 South State Street

Suite 500

Salt Lake City, UT 84111
GMAC Mortgage

4 Walnut Grove

Horshan, PA 19044-0965

Charlie Gohman

Manager, Energy Conservation and Engineering

Arizona Energy Office, Department of

Commerce

3800 North Central Avenue

Suite 1200

Phoenix, AZ 85012

Jean-Paul Gouffray

Program Information Coordinator

South Carolina Energy Office

1200 Main Street, Suite 820

Columbia, SC 29201

Brian Green, SEP Program Manager

Department of Environmental Quality

PO Box 200901

1520 East 6th Avenue

Helena, MT 59620-0901

Ralph Groves

Principle Planner and Program Specialist

Rhode Island State Energy Office

1 Capital Hill, 2nd Floor

Providence, RI 02908

Mike Guerard, Program Manager

Conservation Services Group

40 Wash Street

West Borough, MA 01581

Mike Haake

Energy Specialist, Division of Energy

Missouri Department of Natural Resources

PO Box 176

1500 Southridge Drive

Jefferson City, MO 65102

Hilary Hanel

Portfolio Products Manager

Countrywide Home Loans

35 N. Lake Ave

Ste 35-22

Pasadena, CA 91101 
Steve Harding

Special Projects Coordinator

Governor's Office of Economic Development

711 E Wells Avenue

Pierre, SD 57501-3369

Tom Hattery

Associate Director

Maryland Energy Administration

45 Calvert Street, 4th Floor

Annapolis, MD 21401

John Hemschoot

Director of Policy and Development

Freddie Mac

8200 Jones Branch Dr.

McLean, MD 22102

Brian Henderson

Program Director, Energy Efficiency Services

New York State Energy Research and

Development Authority

Corporate Plaza West

286 Washington Avenue

Albany, NY 12203-6399

Jeff Herholdt

Manager, Energy Efficiency Office

West Virginia Development Office

Building 6, Room 645

State Capitol Complex

Charleston, WV 25305

Daniel Hester

Energy Star Mortgage Director

Chase Manhattan Mortgage Corporation

343 Thronall St

Edison, NJ 08837

Sam Hodges

Senior Architect

USDA-Rural Housing Service

1400 Independence Avenue

Washington, DC 20250

Mike Hodgson

President

ConSol Inc

7407 Tom O'Shanter Drive

Suite 200

Stockton, CA 95210
Dr. Dale Hoffman

Energy Program Specialist, Energy Minerals

Division

Wyoming Business Council

214 W. 15th Street

Cheyenne, WY 82009

Virginia Holman

Senior Single Family Housing Specialist

HUD-FHA

3600 W Board Street

Richmond, VA 23230

Mark Jansen

President

Energy Rated Homes of America

1845 West 18th Street

Indianapolis, IN 46202

Dr. Pierce Jones

Assistant Director

Florida Energy Extension Service (University Of

Florida)

PO Box 110570

102 Rogers Hall, University of Florida

Gainesville, FL 32611

Phil Kaluza

State Energy Program Manager

Alaska Housing Finance Corporation

PO Box 101020

Anchorage, AK 99510-1020

Allen Kramer, Assistant Section Manager

Oregon Housing and Community Services

1600 State Street

Salem, OR 97301-4246

David Lee

Director, Energy Star Homes Program

EPA

401 M Street, SW

$\mathrm{M} / \mathrm{S}$ 6202J

Washington, DC 20460

Felix Lopez

Program Manager, State Agencies Program

Texas Energy Conservation Office

LBJ State Office Building

111 East 17th Street, Room 1114

Austin, TX 78774 
Steven Lowrie, President

National HERO

804 Moorfield Park Drive

Suite 101

Richmond, VA 23236

Christine Lowrie

Executive Director

Virginia HERO

804 Moorfield Park Drive

Suite 101

Richmond, VA 23236

Jerry Lyle, Product Manager

Tennessee Valley Authority

Post Office Box 292409

Nashville, TN 37229-2409

Peggy MacLeod, Program Director

Energy Rated Homes of Connecticut

40 Gillette Street

Hartford, CT 06119

Kathleen Mangold, Management Analyst

Department of Veterans Affairs, Loan Guarantee

Service

810 Vermont Avenue

Mailstop 26A2B

Washington, DC 20420

Rosemary Mape

Chief of Support Services

Department of Environmental Protection

PO Box 2063

400 Market Street, RCSOB

Harrisburg, PA 17105

John Marley

HERS Program Director

Illinois Department of Commerce and

Community Affairs

325 West Adams, Room 300

Springfield, IL 62704-1892

Larry Masland

Program Director, Division Of Energy

Resources

Department of Economic Development

100 Cambridge Street, Room 1500

Boston, MA 02202
Dave McNeil

Building Energy Efficiency/Renewable Energy

Manager

Nevada State Energy Office

1050 East Williams Street, Suite 435

Carson City, NV 89701

Mary G. Meunier

Program Manager, Department of

Administration

Wisconsin Energy Bureau

PO Box 7868

Madison, WI 53707-7868

Joe Murphy

Program Manager, State Energy Program

North Dakota Division of Community Services

State Capitol, 14th Floor

600 East Boulevard Avenue

Bismarck, ND 58505-0170

Patricia O'Loughlin, Business Manager

Fannie Mae

3900 Wisconsin Avenue, NW

Washington, DC 20016

John Osterman

Chief of Energy Financing Division

Nebraska State Energy Office (Dollar and

Energy Saving Program)

PO Box 95085

1111 O Street, Suite 223

Lincoln, NE 68509-5085

Claude Papesh

Energy Rated Homes of America Associate

Energy Rated Homes of Iowa

1001 South 18th Ave

Elberon, IA 52225

Linda Perry, Executive Director

Energy Rated Homes of Mississippi, Inc.

5250 Galaxie Drive

Suite I

Jackson, MS 39204 
Ed Pinero

Director Bureau of Operations/

Pennsylvania's Energy Officer

Department of Environmental Protection, Office

of Pollution Prevention and Compliance

Assistance

PO Box 2063

400 Market Street, RCSOB

Harrisburg, PA 17105

Jim Ploger

Energy Program Manager, Energy Programs

Section

Kansas Corporation Commission

1500 SW Arrowhead Road

Topeka, KS 66604-4027

George Riepe

Assistant Director, Division of Energy

New Jersey Board of Public Utilities

2 Gateway Center

Newark, NJ 07102

Elizabeth Robertson

Director Division of Energy Resources

Georgia Environmental Facilities Authority

100 Peachtree St, NW

Suite 2090

Atlanta, GA 30303-1911

John Sarver

Supervisor of Technical Assistance, Energy

Resources Division

Michigan Department of Consumer and Industry

Services

PO Box 30221

Lansing, MI 48909

Deborah Schachter

Director

Governor's Office of Energy and Community

Services

57 Regional Drive

Concord, NH 03301

Dan Schmidt

Director National Builder Division

Norwest Mortgage, Inc.

6800 College Blvd

Suite 440

Overland Park, KS 66211
Eric Shoberg

Senior Account Representative

Southwest Gas Corporation

3401 Gas Road

Tuscon, AZ 85726

Caroline Shon

Energy Conservation Program Manager

Department of Business Economic Development and Tourism

253 South Beretania, 5th Floor

PO Box 2359

Honolulu, HI 96804-2349

Tei Simmerman

Program Coordinator

Florida Solar Energy Center

1673 Clearlake Rd

Cocoa, FL 32922-5703

Charlie T. Smisson Jr.

Energy Program Administrator, Division of

Facilities Management

State Energy Office

149 Transportation Circle

Dover, DE 19901

Terry Smith

Energy Analyst, Office of Energy Efficiency

Ohio Department of Development

77 South High Street, 26th Floor

Columbus, OH 43266-0101

John Stapleton, Director

Kentucky Division of Energy

663 Teton Trail

Frankfort, KY 40601

Janet Streff, Energy Programs Manager

Energy Division

Minnesota Department of Commerce

121 7th Place East

Suite 200

St. Paul, MN 55101-2145

John Struchen

Acting Chief of Home Improvement Branch

HUD-FHA

4517 th Street

Room 9272

Washington, DC 20410-8000 


\author{
Jim Tait \\ Florida Energy Director \\ Florida State Energy Office \\ 255 Shumard Oak Blvd \\ Tallahassee, FL 32399-2100 \\ David Terry \\ Managing Director \\ National Association of State Energy Officials \\ 1414 Prince Street \\ Suite 200 \\ Alexandria, VA 22314 \\ Richard Tracey \\ Residential Energy Analyst \\ RH Tracey Residential Energy Analyst \\ 7340 Argonne Dr. \\ Marriottsville, MD 21104 \\ Harold Trujillo \\ Bureau Chief, Energy Technology Programs \\ Energy Conservation \& Management Division \\ 408 Galisteo St. \\ PO Box 1948 \\ Santa Fe, NM 87504 \\ Brenda Williams, Director \\ Division of Community and Economic \\ Development Oklahoma Department of \\ Commerce \\ PO Box 26980 \\ 900 N. Stiles \\ Oklahoma City, OK 73126
}




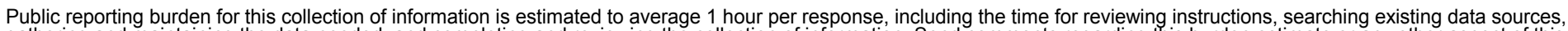

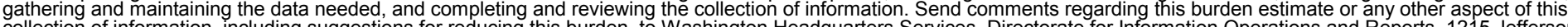
Davis Highway, Suite 1204, Arlington, VA 22202-4302, and to the Office of Management and Budget, Paperwork Reduction Project (0704-0188), Washington, DC 20503.
1. AGENCY USE ONLY (Leave blank)
2. REPORT DATE
April 2000
3. REPORT TYPE AND DATES COVERED
Technical Report

4. TITLE AND SUBTITLE

National Status Report: Home Energy Rating Systems and Energy-Efficient Mortgages

6. AUTHOR(S)

Patricia C. Plympton C.E.M.

7. PERFORMING ORGANIZATION NAME(S) AND ADDRESS(ES)

National Renewable Energy Laboratory
5. FUNDING NUMBERS

BE90-1001

8. PERFORMING ORGANIZATION REPORT NUMBER
9. SPONSORING/MONITORING AGENCY NAME(S) AND ADDRESS(ES)

National Renewable Energy Laboratory

1617 Cole Blvd.

Golden, CO 80401-3393
10. SPONSORING/MONITORING

AGENCY REPORT NUMBER

TP-550-27635

11. SUPPLEMENTARY NOTES

NREL Technical Monitor:

12a. DISTRIBUTION/AVAILABILITY STATEMENT

National Technical Information Service

12b. DISTRIBUTION CODE

U.S. Department of Commerce

5285 Port Royal Road

Springfield, VA 22161

13. ABSTRACT (Maximum 200 words)

The Energy Policy Act of 1992 included several provisions promoting the use of HERS and EEMs, which strengthened efforts to develop a national infrastructure for HERS and to promote the use of EEMs. This report documents HERS and EEMs activities since 1992 by the U.S. Department of Energy, the U.S. Environmental Protection Agency, the U.S. Department of Housing and Urban Development, mortgage lenders, and other organizations.

Though the process of establishing HERS has faced some barriers, this report shows that, as of November 1999, home energy ratings were available in 47 states and the District of Columbia, which represents a significant increase from 1993 when home energy ratings were available in 17 states. Both national and state organizations have developed HERS and related residential energy-efficiency programs.

The availability and use of EEMs has also increased significantly. The number of EEMs supported by the Federal Housing Administration has increased more than eight times in the last three years. More than $\$ 2.5$ billion in federally supported EEMs have been issued to date. Several national lenders offer EEMs, and six states have state-specific EEM or loan programs. EEMs have been used to finance energyefficient homes in every state.

14. SUBJECT TERMS
Home Energy Rating Systems, HERS, Energy-Efficient Mortgages, EEMs, Status Report

17. SECURITY CLASSIFICATION OF REPORT Unclassified
18. SECURITY CLASSIFICATION OF THIS PAGE Unclassified
19. SECURITY CLASSIFICATION OF ABSTRACT Unclassified
15. NUMBER OF PAGES

16. PRICE CODE

20. LIMITATION OF ABSTRACT

UL 